\title{
Review paper \\ High-pressure granulites of the Bohemian Massif: recent advances and open questions
}

\author{
Jana KOTKOVÁ
}

Institute of Geological Sciences, Masaryk University, Kotlářská 2, Brno, Czech Republic; kotkova@sci.muni.cz

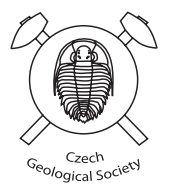

This paper presents a summary of recent knowledge on the high-pressure (HP) granulites of the Bohemian Massif, focusing mainly on the felsic ones with the peak mineral assemblage garnet-kyanite-ternary feldspar-quartz. There are several lines of evidence for the HP character of these rocks, such as the coexistence of kyanite, ternary feldspar, garnet and rutile, high grossular content in garnet indicative of operation of the reaction An = Grs $+\mathrm{Ky}+\mathrm{Qtz}$ and geothermobarometric constraints, as well as association with eclogites, mantle ultramafic rocks and ultra-high-pressure crustal rocks. Established mineral reactions and major-element zoning of garnet are indicative of post-peak decompression and cooling of granulites. Exhumation-related P-T path can be reconstructed using these, along with the P-T estimates for successive mineral assemblages in case they are preserved. Published P-T paths for the HP granulites of the Bohemian Massif are in general dominated by initial near-to-isothermal decompression, followed by near-to-isobaric cooling stage. However, the peak and post-peak history of some granulite bodies differs from this Moldanubian-type evolution. Mostly concordant U-Pb ages for spherical "metamorphic” zircon cluster around $340 \mathrm{Ma}$. Arguments for the more common interpretation of this age as dating the HP granulite phase or the alternative one attributing it to the medium-pressure stage are listed. Fitting the P-T estimates to the age data from various geochronometers (P-T-t paths) allows exhumation and cooling rate of granulites to be constrained. Average exhumation rate calculated for the Bohemian HP granulites is at least $4 \mathrm{~mm} / \mathrm{yr}$, whereas the initial rate could be as high as 9-18 mm/yr. Initial cooling rate has been estimated at $25-100{ }^{\circ} \mathrm{C} / \mathrm{Myr}$. These high rates, but also preservation of the peak assemblages, reflect rapid exhumation of the HP granulite complexes of the Bohemian Massif.

It is still a matter of debate what were the protoliths of the felsic HP granulites; arguments for major HP melting period giving rise to these rocks and the alternative view of the granulites as metamorphosed granites (or orthogneisses) are presented. Tectonic scenarios for the HP granulites formation and exhumation can be subdivided into two groups: whereas some authors envisage deep Early Variscan subduction and subsequent thrusting and/or buoyancy-driven exhumation, the others postulate granulite formation due to the homogeneous crustal thickening and their exhumation through vertical extrusion of the orogenic lower crust.

Keywords: high-pressure granulites, $P-T$ path, zircon dating, protolith, tectonic processes, Bohemian Massif Received: 13 January 2007; accepted 25 May 2007; handling editor: V. Janoušek

\section{Introduction}

A glance at the geological map of the Bohemian Massif (BM) shows that there are numerous granulite exposures (Fig. 1). Predominant high-pressure (HP) granulites were recognized as exceptional since they were first described by von Justi (1754), who appreciated them for their "semi-precious" stone appearance of a light crystalline rock with dark, biotite-bearing bands and disseminated garnet. It was much later that the HP granulites were recognized as rocks with a potential to record conditions of their formation deep in the Earth's crust and the history of subsequent exhumation to the surface. Recent decades have seen important advances in our understanding of processes related to the formation and evolution of these rocks, especially due to refinements in analytical and quantitative techniques in petrology and geochemistry. These enable us to decipher the complex metamorphic, deformational and temporal record they contain as a reflection of tectonic processes in the Earth's crust in geological history.

Our understanding of the Bohemian granulites has been summarized at various times by Jakeš (1969), Fiala et al. (1987), and more recently by O’Brien and Rötzler (2003) and O'Brien (2006). The international scientific community has had opportunities to study the HP granulites of the BM in the field and to contribute to their knowledge at the international workshops (Fišera and Kotková 1992; Janoušek 2004).

The aims of the present paper are (i) to update knowledge on granulite-forming processes, including possible protoliths, the exhumation-related P-T evolution, absolute age determinations and geotectonic interpretations, (ii) to address open and disputed questions related to the above points and (iii) to make reference to less well known, older works of local geologists, who were often 


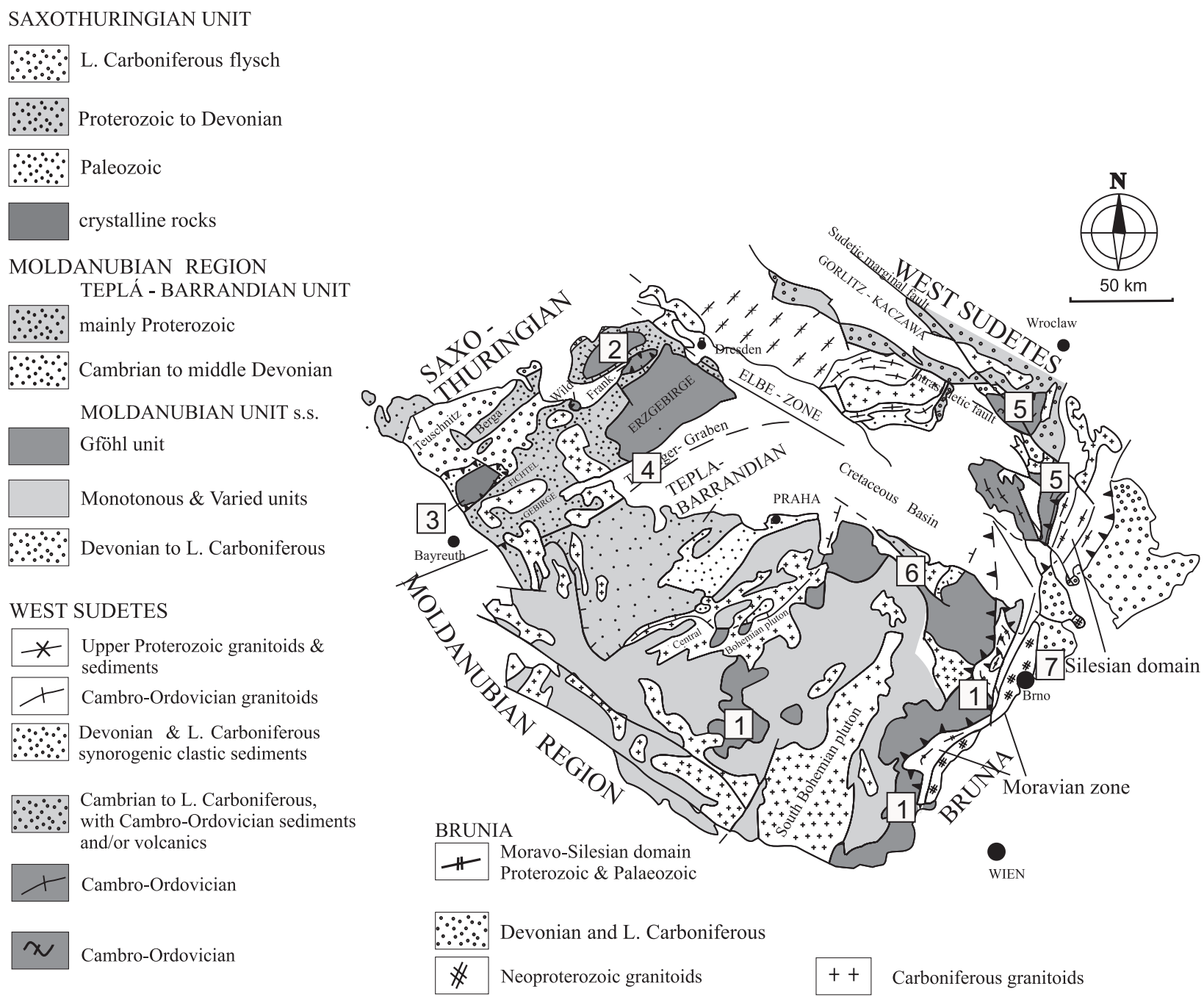

Fig. 1 Structural map of the Bohemian Massif showing distribution of the granulite massifs (adapted after Franke 2000). 1 - Moldanubian Zone of southern Bohemia, Moravia and Lower Austria, 2 - Saxonian Massif, 3 - Münchberg Massif, 4 - Ohře Crystalline Complex, 5 - Góry Sowie and Snieznik Mts., 6 - Kutná Hora-Svratka Crystalline Complex, 7 - Viséan conglomerates

the first to describe many important aspects of granulite occurrences and genesis. This paper deals mainly with the most abundant felsic HP granulites (Fig. 2a-b). More details on intermediate and mafic granulites, occurring mostly as conformable layers of several centimetres to several metres thick in the felsic granulites, can be found in other papers (e.g. Carswell and O’Brien 1993; Cooke 2000; Cooke et al. 2000; Janoušek et al. 2006b).

\section{Characteristics of the HP granulites of the Bohemian Massif}

The separate granulite metamorphic facies was defined on the basis of mineral assemblages in basic rocks. The high-temperature (HT) conditions characteristic of this facies are indicated by the presence of orthopyroxene, whilst the upper pressure boundary with the eclogite facies corresponds to the breakdown of plagioclase. Although the light, felsic granulites had been described from the Saxonian Granulite Massif in Germany, its type locality, in 1803 by Weiss as Weisstein (white rock), these rocks clearly do not fit in the classical facies definitions (see e.g. Winkler 1976; O’Brien 2006). Moreover, as pointed out by Schreyer (1985), the P-T grids existing at that time ended at lithostatic pressures of 10-12 kbar, the maximum pressures attainable in normal-thickness crust. Restricted pressure extents limited the $\mathrm{P}-\mathrm{T}$ grids in the outstanding review of Harley (1989) as well, whereas the BM granulites record higher pressures (see Tab. 1). Nevertheless, already Pin and Vielzeuf (1983) distinguished the HP granulites in the internal zones of the European Variscides from the younger medium- to low-pressure ones. Apart from the Bohemian Massif, the HP granu- 

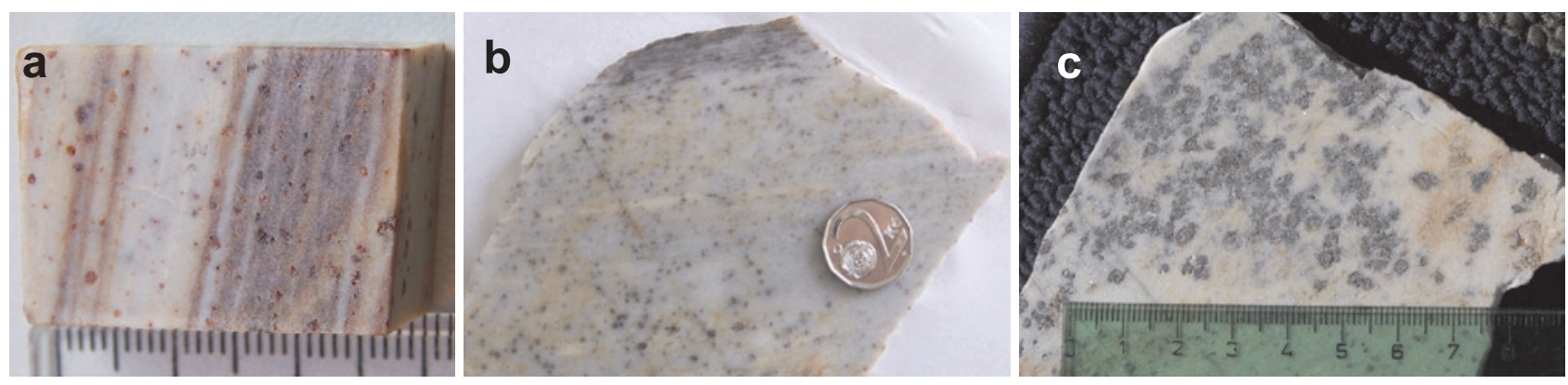

Fig. 2 Photographs showing the macroscopic appearance of the felsic granulites of the BM. a - banded felsic granulite (dark bands enriched in biotite), Rabštejn, Náměšt' Granulite Massif. b - leucogranulite and c - hyperpotassic granulite, Plešovice quarry, Blanský les Massif.

lites with similar lithology, mineral assemblages and associated mantle rocks occur also in other parts of the European Variscan Belt, like Vosges, Massif Central and Armorican Massif in France or Black Forest in Germany (Pin and Vielzeuf 1983). Regional tectonic importance of the HP felsic granulites cannot be questioned anymore, as Bohlen (1987) did in his review on granulites.

The peak mineral assemblage of the felsic granulites of the BM is garnet-kyanite-ternary feldspar (mesoperthite)-quartz (Fig. 3a-c), while the subordinate mafic granulites contain garnet and clinopyroxene in addition to quartz and feldspars. Orthopyroxene is not a characteristic primary mineral phase of any of these granulite types. High $\mathrm{Fe} / \mathrm{Mg}$ ratio and $\mathrm{Al}$ contents in the typical felsic granulites favour crystallization of aluminosilicate and almandine-rich garnet instead of orthopyroxene (Vrána and Jakeš 1982). Felsic Grt-Opx-bearing HP granulites with slightly lower Si and higher Fe and Ca contents occur only rarely (Vrána and Jakeš 1982; Fiala et al. 1987; Carswell and O’Brien 1993).

Felsic granulites of the BM are high-K calc-alkaline, weakly peraluminous rocks, which contain normative plagioclase $(A n>10)$. The whole-rock composition and normative Qtz-Afs-Pl contents of the felsic granulites correspond to (leuco-) granites (Fiala et al. 1987; Kotková 1993; Kotková and Harley 1999; Janoušek et al. 2004). These rocks show heterogeneous whole-rock composition on outcrop scale, which is reflected in the presence of plagioclase (or antiperthite) along with mesoperthite in $\mathrm{SiO}_{2}$-poorer, Ca-richer types. Alkali feldspar compositions (hyperpotassic types dominated by K-feldspar or sodium granulite types with $\mathrm{Ab}$ » Kfs) occur rarely, too (Schreyer et al. 1975; Grew 1986; Vrána 1989; Vrána et al. 2005; Janoušek et al. this volume). Dark, garnet and biotite-rich layers of metasedimentary (metapelitic) origin, occurring within the felsic granulites, were not studied in detail yet.

The coexistence of garnet, original ternary feldspar (now mesoperthite) and kyanite (e.g. Fig. 3a, c) document not only high-temperature but also high-pressure conditions of the felsic granulites formation. The high pressures are reflected by Grs-rich composition of garnet, indicative of the operation of reaction $\mathrm{An}=\mathrm{Grs}+\mathrm{Ky}+$ Qtz. As the position of the Grt-in/Opx-out reaction for granitic compositions in $\mathrm{P}-\mathrm{T}$ space is similar to that of the Pl-out reaction in tholeiites, these felsic HP rocks actually formed under eclogite-facies conditions (see O’Brien and Rötzler 2003 and O'Brien 2006 for detailed discussion). In mafic granulites, orthopyroxene is a secondary phase, forming during decompression-driven reactions (Vrána and Jakeš 1982; Carswell and O’Brien 1993). It has to be noted though that the peak and postpeak history of the BM granulites is not uniform. In the Moldanubian granulite type, retrievable HP assemblages were overprinted at MP/HT conditions. Other types not exhibiting HP stage neither any decompression-related features (e.g. major part of the Lišov Massif granulites, see Chapter 7.4) or without any MP/HT overprints after the HP-HT metamorphic peak (Ohře Crystalline Complex, Kutná Hora-Svratka Crystalline Complex) occur (see Tab. 1).

In an attempt to clarify granulite nomenclature, a discussion was held at the granulite meeting in Saxony in 1968. Its results were summarized by Behr et al. (1971) and Mehnert (1972). It was proposed, that "granulite is a fine- to medium-grained metamorphic rock composed essentially of feldspar with or without quartz. Ferromagnesian minerals are predominantly anhydrous. The texture is mainly granoblastic, the structure is gneissose to massive. Some granulites contain lenticular grains or lenticular aggregates of quartz." For the predominant felsic granulites with less than $5 \%$ mafic phases, the term leucogranulite has been used (Fiala et al. 1987).

\section{HP granulite occurrences in the Bohemian Massif}

High-pressure granulites occur in the following geological units of the Bohemian Massif (Fig. 1):

- Moldanubian Zone in south Bohemia, Moravia and Lower Austria. 

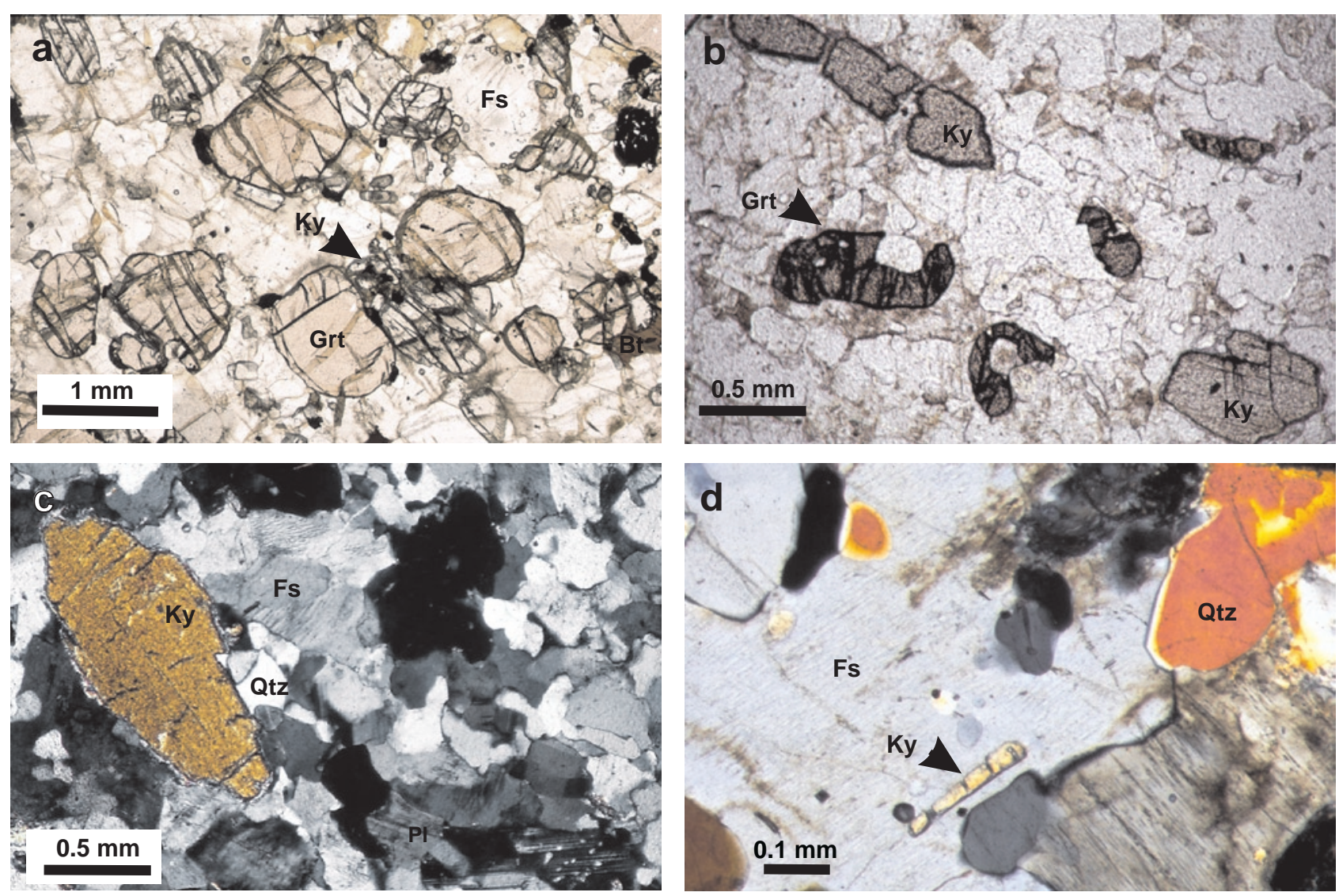

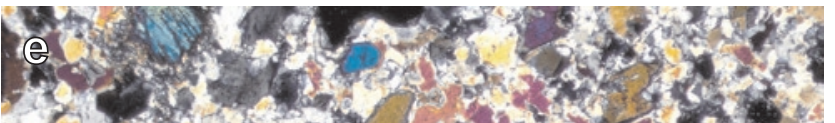

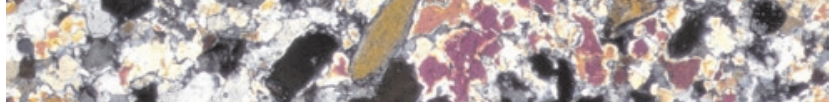

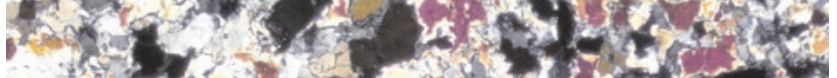

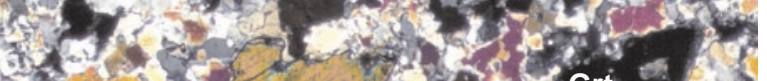

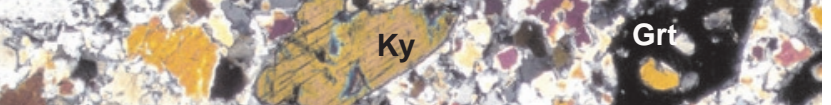

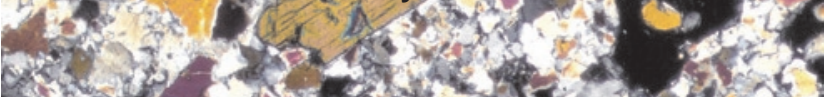
P.t.

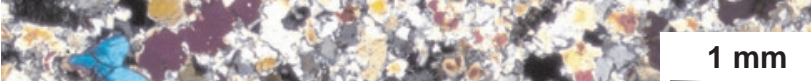

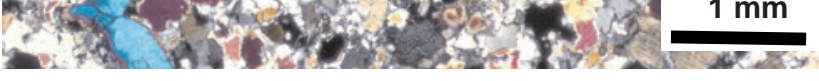

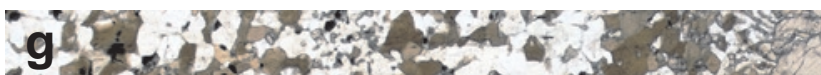

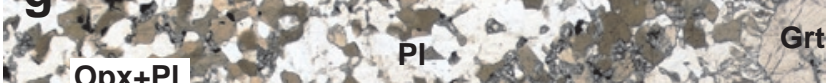
- EOpx+PI-

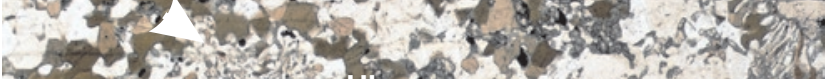

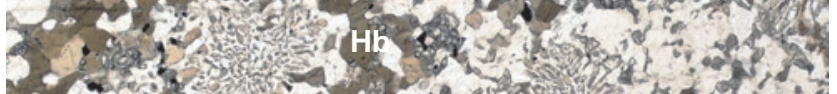

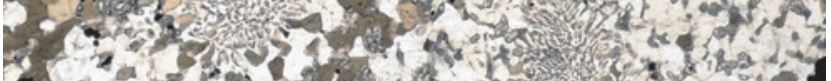

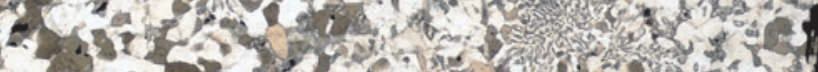

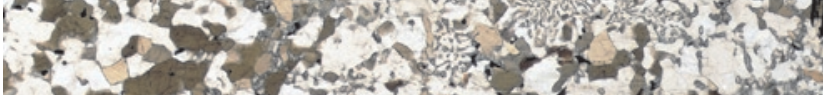

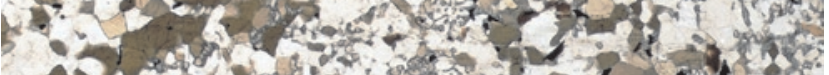
$11 \mathrm{~mm}$ \%

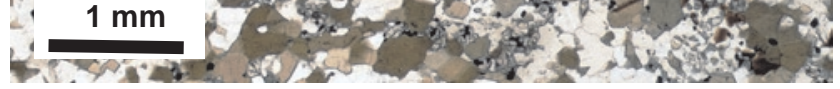
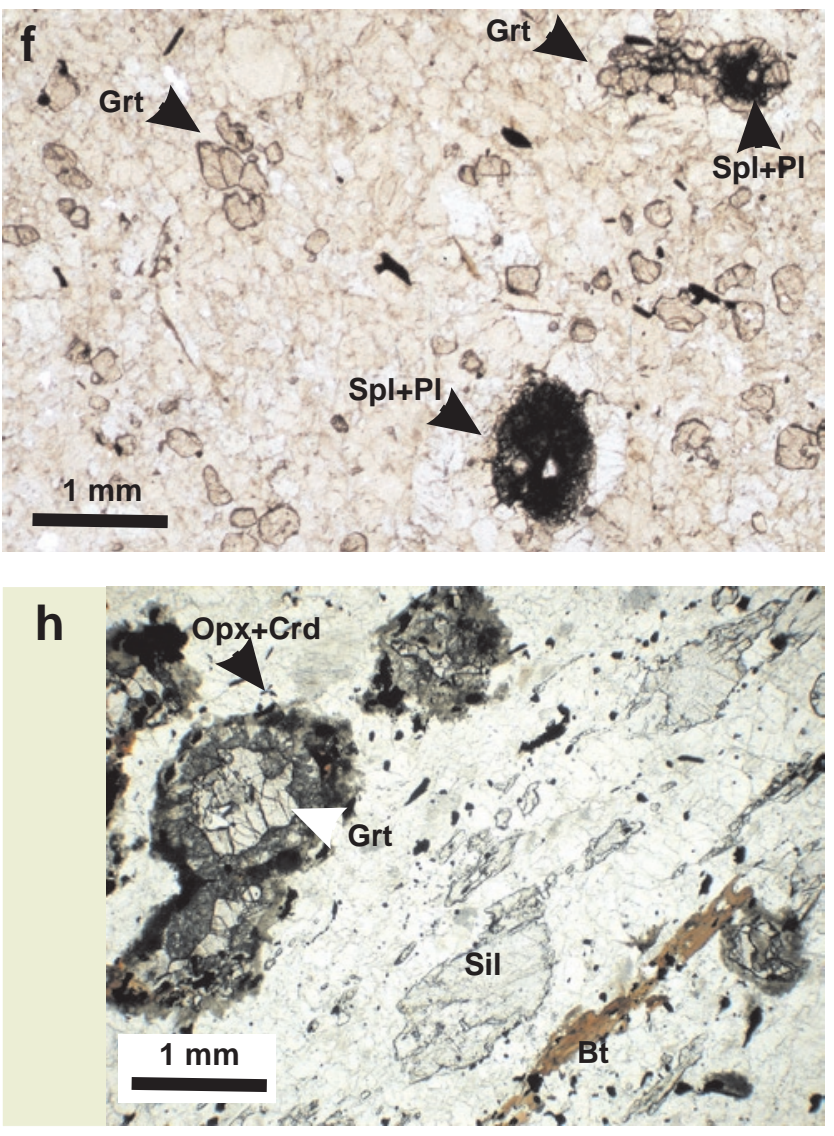
Fuchs and Matura (1976) postulated present position of granulites on the top of the Gföhl Unit, the uppermost of the stacked nappes (Varied and Monotonous Unit) of the Moldanubian Zone. The granulite massifs were later interpreted as isolated klippen of an original, regionally extensive, nappe (Tollman 1982, 1995; Matte et al. 1990). This model was later disputed by Vrána and Šrámek (1999) for the south Bohemian Granulite Complex and Racek et al. (2006) for part of the Lower Austria (Chapter 10). Structural situation in some parts of the Bohemian Massif is clearly more complex due to superposition of several phases of intense structural reworking (Vrána 1979; Franěk et al. 2006).

- Saxothuringian Zone - Saxonian Granulite Massif (SGM), Münchberg Massif (MM) and small occurrences in Central Erzgebirge within the so-called GneissEclogite Unit in Germany, and granulites of the Ohře (Eger) Crystalline Complex (OCC).

The MM has been considered as an isolated nappe klippe (e.g. Franke 1984). In the Central Erzgebirge, the HP-HT Gneiss-Eclogite Unit is situated above the lower-grade Grey and Red Gneiss Unit and has been interpreted as a dismembered nappe (Willner et al. 1997). Granulites of the OCC (along with the granulites of the Zöblitz area) may represent an uppermost klippe within the stacked nappe pile of Central Erzgebirge. Their steep E-W-trending foliation (Kotková 1993) was interpreted as a result of refolding by N-Sdirected shortening (see Konopásek and Schulmann 2005 and references therein). Recent geophysical surveys of the SGM have confirmed its independence

\section{$\Leftarrow$}

Fig. 3 Photomicrographs showing mineral assemblages of successive granulite stages. Fs = ternary feldspar (mesoperthite)

Ohře Crystalline Complex, felsic granulites

a - garnet and kyanite within quartzofeldspathic matrix, PPL, granulite of granodiorite composition, SW of former village of Donín, SW of Kadaň. b - garnet and kyanite in quartzofeldspathic matrix, PPL, leucogranulite, disused quarry in Stráž nad Ohří. c - large kyanite with incipient muscovite and quartz formation at the rim, mesoperthite and quartz with high-energy boundaries are also apparent, XPL, leucogranulite, disused quarry in Stráž nad Ohří.

Blanský les Massif, leucogranulites

d - kyanite inclusion in mesoperthite, XPL, $1.3 \mathrm{~km}$ SW of Chvalovice, $\mathrm{N}$ part of the Blanský les Massif. e - garnet and kyanite in fine-grained recrystallized matrix of Pl, Kfs and Qtz, XPL, Zrcadlová Hut' quarry. f - garnet in the matrix and around spinel and plagioclase aggregates forming at the expense of kyanite, PPL, Zrcadlová Hut' quarry.

Lišov Massif, mafic granulites

g - orthopyroxene and plagioclase symplectites after garnet which is partly preserved (upper right) in re-equilibrated matrix of plagioclase and hornblende, PPL, borehole LV-1, S of Lišov.

Strongly peraluminous granulite clast in Viséan Luleč conglomerates, Drahany Uplands

$\mathbf{h}$ - garnet with cordierite and orthopyroxene coronas in matrix of plagioclase, K-feldspar, quartz and biotite, PPL, Luleč quarry. from the Erzgebirge Unit and possible continuation of the SGM to the SW. Exhumation of the SGM has been attributed to tectonic underplating followed by extensional unroofing, with the extensional geometry largely preserved due to its external position during the later NW-directed thrusting of the Erzgebirge nappe pile (DEKORP and Orogenic Processes Working Groups 1999). Alternatively, the discontinuity of the Erzgebirge Unit and the SGM could result from their juxtaposition due to two-phase Variscan thrusting, of first the Erzgebirge to the NW and then the SGM to the south, the latter exhuming granulites from deeper levels (Krawczyk et al. 2000).

- Sudetes - Gory Sowie (Poland) and Snieznik Crystalline Unit (from Poland to the Czech Republic - Rychleby Mts.); the former is a fault-bounded body interpreted among others as a klippe or part of a larger thrust sheet (see O’Brien et al. 1997 for references). The latter exhibits vertical foliation with transitions to flat fabrics and is interpreted as an extension-related core complex, the result of transpression-related nappe stacking or vertical extrusion and sideways horizontal thrusting at depth (see Gordon et al. 2005 and references therein).

- Kutná Hora-Svratka Crystalline Complex - Běstvina granulite body located in the uppermost of the three nappe units thrust over the Moldanubian Zone (Synek and Oliveriová 1993; Vrána et al. 2005)

- granulite clasts occurring in the Upper Viséan sediments of the Drahany Uplands at the eastern margin of the Bohemian Massif (Štelcl 1960; Vrána and Novák 2000; Čopjaková et al. 2005; Kotková et al. in press).

\section{Other granulite types of the Bohemian Massif}

Apart from the predominant HP granulites (sensu Pin and Vielzeuf 1983), treated in this paper, other granulite types occur in the Bohemian Massif. These occurrences include:

- charnockitic rocks brought up to the surface by basaltoid volcanism in the České středohoři Mts. (Opletal and Vrána 1989)

- granulite-facies two-pyroxene-bearing Sarleinsbach type of Weinsberg granite, interpreted alternatively as co-genetic magmatic cumulate or relict charnockite (Finger and Clemens 1993; Klötzli et al. 2000)

- biotite-orthopyroxene-bearing "gneiss" granulites from Regen (Blümel and Bues 1995)

- garnet-biotite-bearing HP granulites of meta-greywacke composition from Běstvina (Vrána et al. 2005). 
Tab. 1 Summary of the (more recent) P-T estimates for HP granulites of the Bohemian Massif

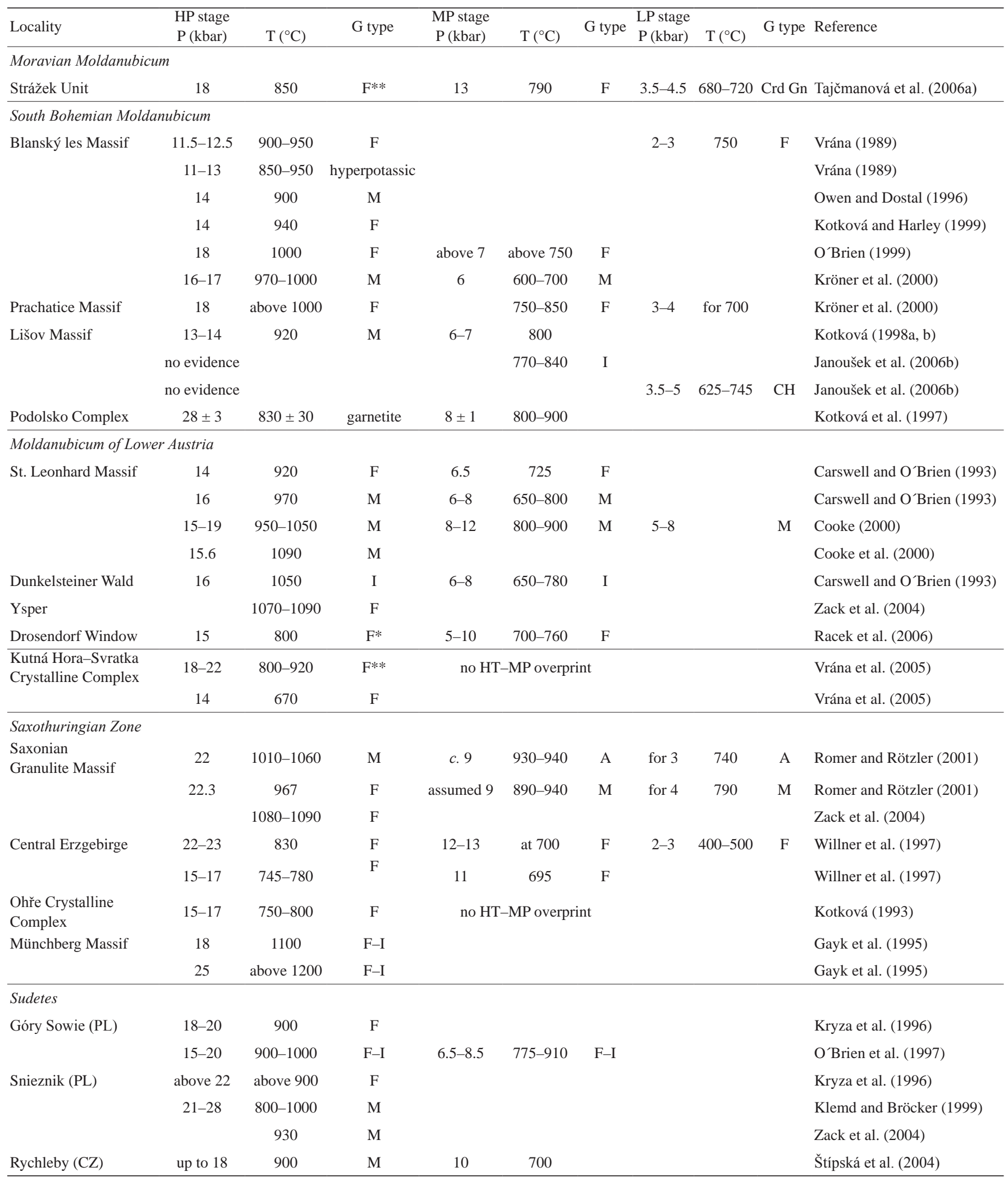

Legend:

F - felsic, I - intermediate (commonly Opx-bearing), M - mafic (commonly Cpx but also Fs/Qtz-bearing), A - Al-rich, G - granulite, CH - charnockite, $\mathrm{Gn}$ - gneiss; * - pseudosection approach takes $\mathrm{Pl}+\mathrm{Kfs}$ and not ternary feldspar as primary peak phases; ** - Bt and Pl considered as primary peak phases 


\section{Pressures (depths) and temperatures of the HP granulite formation}

Several lines of evidence prove that felsic granulites formed very deep, at depths corresponding to the base of the thickened crust or in the upper mantle.

The spatial association of the felsic granulites with eclogites and ultrabasic rocks including garnet peridotites, has long been recognized (see Fediuková 1965; Jakeš 1969; Pin and Vielzeuf 1983; Carswell 1991). Observed $\mathrm{Ni}$ and $\mathrm{Cr}$ enrichments in acid granulites have been explained as being due to interaction between mantle and crustal material (Fiala et al. 1987). Garnetiferous ultramafic rocks from the Gföhl Unit have geochemical signatures of HP melts, crystallized in the lithospheric mantle (Medaris et al. 1995, 2006; Becker 1996). The mean Sm-Nd mineral isochron ages correspond to 336 and $339 \mathrm{Ma}$, although older ages of 370-380 Ma were also obtained (Becker 1997; Medaris et al. 2005 and references therein). These geochronological data are comparable to the U-Pb zircon ages for HP granulites (see Chapters 8.2 and 9).

A second line of evidence is the occurrence of ultrahigh-pressure (UHP) rocks described from the granulite-bearing units, documenting deep subduction of the continental crustal material (Kotková et al. 1997; Vrána and Frýda 2003). Moreover, these rocks exhibit granulitefacies overprint. Coesite and diamond have been found in the Central Erzgebirge (Seidenbach - Nasdala and Massonne 2000; Massonne 2001) and the presence of possible coesite or other phases indicative of UHP conditions have been documented from Orlica-Snieznik Mts. (e.g. Klemd and Bröcker 1999) and Münchberg Massif granulites (see O’Brien and Rötzler 2003 for other references).

A third indication of HP-HT conditions is the coexistence of hypersolvus ternary feldspar, kyanite, garnet and rutile (Fig. 3a-d). This is documented by the presence of kyanite inclusions in large mesoperthite grains (Fig. 3d) and of mesoperthite, kyanite and rutile inclusions in garnet (e.g., Vrána 1989; Kotková 1993; Carswell and O’Brien 1993). The composition of garnet from hyperpotassic granulites is comparable to that of garnet produced by HP-HT melting experiments on similar whole-rock compositions (Vrána 1989 and references therein; see Tab. 1).

Fourth are $\mathrm{P}-\mathrm{T}$ estimates yielded by independent geothermobarometers, using the composition of minerals coexisting at peak P-T conditions, or multi-equilibria studies using internally consistent thermodynamic data. After Scharbert and Kurat (1974; 11 kbar and $760^{\circ} \mathrm{C}$ derived based on experimental data existing at that time), the first high-pressure estimates for the felsic granulites of the BM (from southern Bohemia) were presented by Pin and Vielzeuf (1988). They used published compositional data and the GASP barometer based on the reaction Grs $+2 \mathrm{Ky}+\mathrm{Qtz}=3 \mathrm{An}$, initially calibrated by Newton and Haselton (1981) and obtained pressures close to $14 \mathrm{kbar}$ assuming an equilibration temperature of $800^{\circ} \mathrm{C}$.

To estimate more closely the temperature, resp. pressure of equilibration of the early HP-HT felsic granulite assemblages, the original hypersolvus ternary feldspar compositions (now exsolved mesoperthite) have to be re-integrated and An content of the ternary feldspar has to be used. More variable reaction equilibria in the associated intermediate and mafic garnet-pyroxene-bearing assemblages provide additional (or even better) constraints. The estimated minimum $\mathrm{P}-\mathrm{T}$ conditions of $\sim 16 \mathrm{kbar}$ and $1000^{\circ} \mathrm{C}$ (Carswell and O’Brien 1993; see also O’Brien and Rötzler 2003 and Tab. 1) rank the HP granulites of the BM to ultra-high-temperature rocks. Recently, temperatures above $1000^{\circ} \mathrm{C}$ have been determined using an empirical geothermometer based on the $\mathrm{Zr}$ content in rutile in quartz- and zircon-saturated felsic granulite assemblages (Zack et al. 2004).

Cooke et al. (2000) re-evaluated a sample of the mafic pyroxene-bearing granulites from Lower Austria, for which peak P-T conditions of only 8-9 kbar and $750{ }^{\circ} \mathrm{C}$ were estimated by Petrakakis and co-workers (see Petrakakis 1997 and references therein). Cooke et al. (2000) demonstrated that the peak P-T conditions (16-17 kbar, $>900{ }^{\circ} \mathrm{C}$ ) corresponded to those previously determined for the Moldanubian granulites. In addition, they pointed out that the correct identification of the coexisting phase compositions of different $\mathrm{P}-\mathrm{T}$ evolutionary stages is essential for valid interpretation of these high-grade rocks. This problem is explored in the work of O'Brien (in press), which critically addresses the interpretation of Štípská and Powell (2005). These authors questioned the UHT character of the granulites of the BM, arguing that the ternary feldspar is a preserved relic from the granulite magmatic protolith.

The overview of $\mathrm{P}-\mathrm{T}$ estimates for the $\mathrm{HP}$ granulites of the BM is presented in Tab. 1.

\section{Other lithological types from the HP granulite complexes}

Granulite massifs contain layers or lenses of lithologically distinct rock types, representing specific chemical systems with unusual mineral assemblages useful for determination of $\mathrm{P}-\mathrm{T}$ evolution and petrogenetic processes. They document that the HP (UHP)-HT conditions were attained also by other materials. These are for instance $\mathrm{Al}-\mathrm{Mg}$-rich, plagioclase-dominated granulites with kornerupine from Waldheim in Saxony (Schreyer et al. 1975; Grew 1986, 1989), granulite-facies garnet-fassaitic pyroxene skarn from south Bohemian Blanský les 
Massif (Vrána 1987), or ultrahigh-pressure garnetites occurring in the Gföhl gneisses in south Bohemia and western Moravia (Kotková et al. 1997; Vrána and Frýda 2003).

\section{Exhumation of granulite complexes}

Estimates of the peak P-T conditions for the granulites are hampered by common "retrograde" overprints. For this reason, they are usually reported as "minimum estimates". On the other hand, interpretation of these overprints enables us to follow the path along which the rock was exhumed towards the Earth's surface. These so-called $P-T$ paths (see e.g. Spear 1993) can be reconstructed in a qualitative or quantitative way - both approaches being backed by a careful study of equilibrium mineral assemblages of the successive evolutionary stages, relationships between deformation and mineral crystallization, and mineral reactions. The latter are especially important as they link the individual evolutionary stages and specify the direction in which the rocks moved in terms of $\mathrm{P}$ and $\mathrm{T}$ space (clockwise vs. anticlockwise $\mathrm{P}-\mathrm{T}$ path). The reactions are summarized in detail below. The quantitative approach necessitates the study of mineral zoning, calculation of $\mathrm{P}-\mathrm{T}$ conditions for individual mineral assemblage stages and absolute age determinations for these stages (P-T-t path). Methods of P-T-t paths reconstruction in HP-HT granulites are, however, not as standard or straightforward as it may appear. Some of the main pitfalls commonly neglected are that the newly formed minerals do not necessarily represent equilibrium assemblages. Presence of compositional gradients in minerals themselves qualify the mineral assemblage as disequilibrium ones - and use of newly-formed phases like biotite, the formation and composition of which has been controlled by element diffusivity, for thermobarometry, brings senseless results (see e.g. Spear 1993). The complex topic of $\mathrm{P}-\mathrm{T}$ determination in the HP granulites of the BM has been treated in detail by Carswell and O’Brien (1993), Cooke (2000), O’Brien and Rötzler (2003) and Cooke and O'Brien (2001). More recent P-T estimates for the successive stages of granulite evolution are summarized in Tab. 1.

\subsection{Mineral reactions}

Mineral reactions indicative of changes in $\mathrm{P}-\mathrm{T}$ conditions following the HP-HT granulite stage can be observed under optical microscope. Particularly useful are rocks with intermediate to basic compositions enriched in $\mathrm{Al}$ and other elements (Fe, Mg, Ca or a combination of these), which results in a more variable mineralogy. A list of metamorphic reactions is given below, in general ranging from higher to lower $\mathrm{P}-\mathrm{T}$. In the text $F$ refers to felsic Grt-Ky-bearing granulites, $M$ to mafic Grt-Cpx-Pl-Qtzbearing granulites, $I P$ to intermediate Grt-Opx-bearing granulites, and $A$ to granulites and (UHP) garnetites relatively enriched in $\mathrm{Al}, \mathrm{Fe}$ and $\mathrm{Mg}$ or $\mathrm{Ca}$. An attempt has been made to provide reference to the first described occurrence in the various lithological types. Where not stated otherwise, the reactions were reported by Carswell and O'Brien (1993), who in many cases presented them as calibrated reaction equilibria. Selected mineral reactions are shown in Fig. 4.

\subsubsection{Reactions indicative of decompression}

- plagioclase coronas around kyanite or its breakdown products (Fig. 5a-c; IP - Vrána and Jakeš 1982, F O'Brien 1999; Tajčmanová et al. 2006a; A - Rötzler and Romer 2001),

- F: ilmenite rimming and partly replacing rutile,

- phase transformation of kyanite to sillimanite (Fig. 4c) or even andalusite (F - Behr 1961; Fediuková 1971; Scharbert 1971; Staňková 1982; A - Grew 1986),

- kyanite breakdown into spinel (or corundum) + plagioclase (Figs 3f, 4d, 5a-b; IP - Suess (1900, in Scharbert 1971); Vrána and Jakeš 1982, M - Owen and Dostal 1996a, F - O’Brien 1999, Vrána 1992a and A - Rötzler and Romer 2001; Vrána and Frýda 2003),

- formation of sapphirine and plagioclase symplectites by the reaction of garnet, kyanite and spinel (A - Rötzler and Romer 2001),

- garnet coronas around kyanite (Fig. 5d; Scharbert 1971) or around the anorthite and spinel mosaics (M - Owen and Dostal 1996a; F - O’Brien 1999),

- orthopyroxene and cordierite (+ sapphirine or spinel) symplectites around garnets (Figs 3h, 5e-f; A - Owen and Dostal 1996b; Kotková et al. 1997, in press),

- cordierite and quartz coronas around garnet (Fig. 4f; F - Staňková 1982; Vrána 1992a),

- formation of orthopyroxene and plagioclase coronas around garnet or complete garnet replacement by reaction of garnet and quartz (and clinopyroxene) (Figs 3g, 5e; M - Vrána and Jakeš 1982) or orthopyroxene, plagioclase and spinel symplectites in quartz-deficient domains (M - Kotková 1998b),

- formation of clinopyroxene, plagioclase and quartz symplectites after a former (peak?) $\mathrm{Na}-\mathrm{Al}$-rich clinopyroxene, enclosed in garnet (M).

\subsubsection{Reactions indicative of cooling}

- orthopyroxene lamellae in large clinopyroxene grains (M),

- rutile exsolutions from HT garnet (F - Vrána 1989; O’Brien 1999) 
- formation of mesoperthite (Figs 3c-d; F) and antiperthite (M) by exsolution of the original ternary feldspar,

- further plagioclase and K-feldspar recrystallization in fine-grained mosaic (Fig. 3e; M, F),

- growth of corona-like garnet enclosing spinel and plagioclase aggregates (Fig. 3f; F - O’Brien 1999; M - Owen and Dostal 1996a),
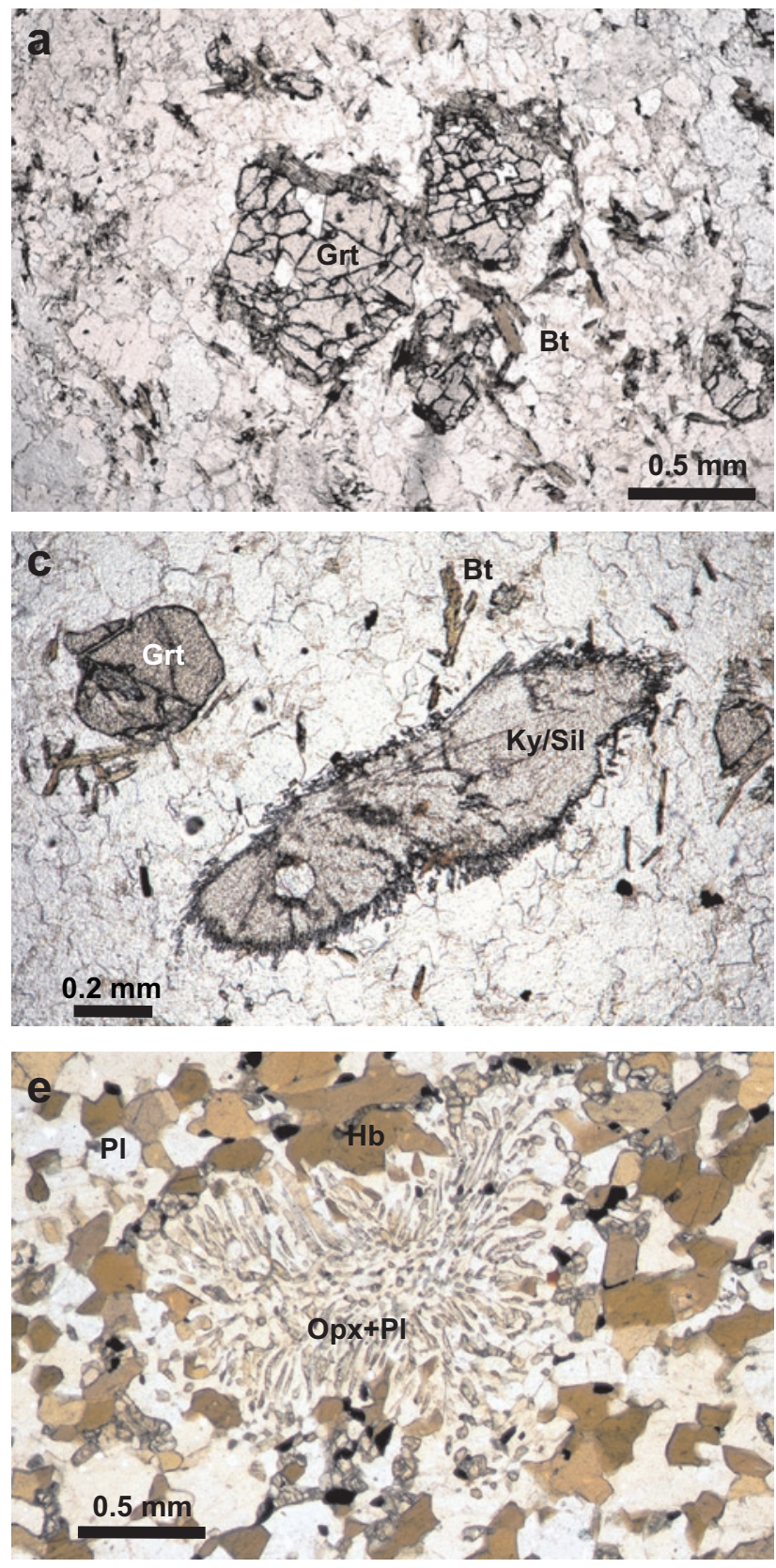

- biotite ( \pm sillimanite) formation from garnet (Fig. 3a; A),

- biotite \pm amphibole formation from pyroxene (M),

- muscovite (+ quartz) formation from kyanite (Fig. 4b; F - Kotková 1993),

- formation of andalusite from sillimanite (F - Fediuková 1971)
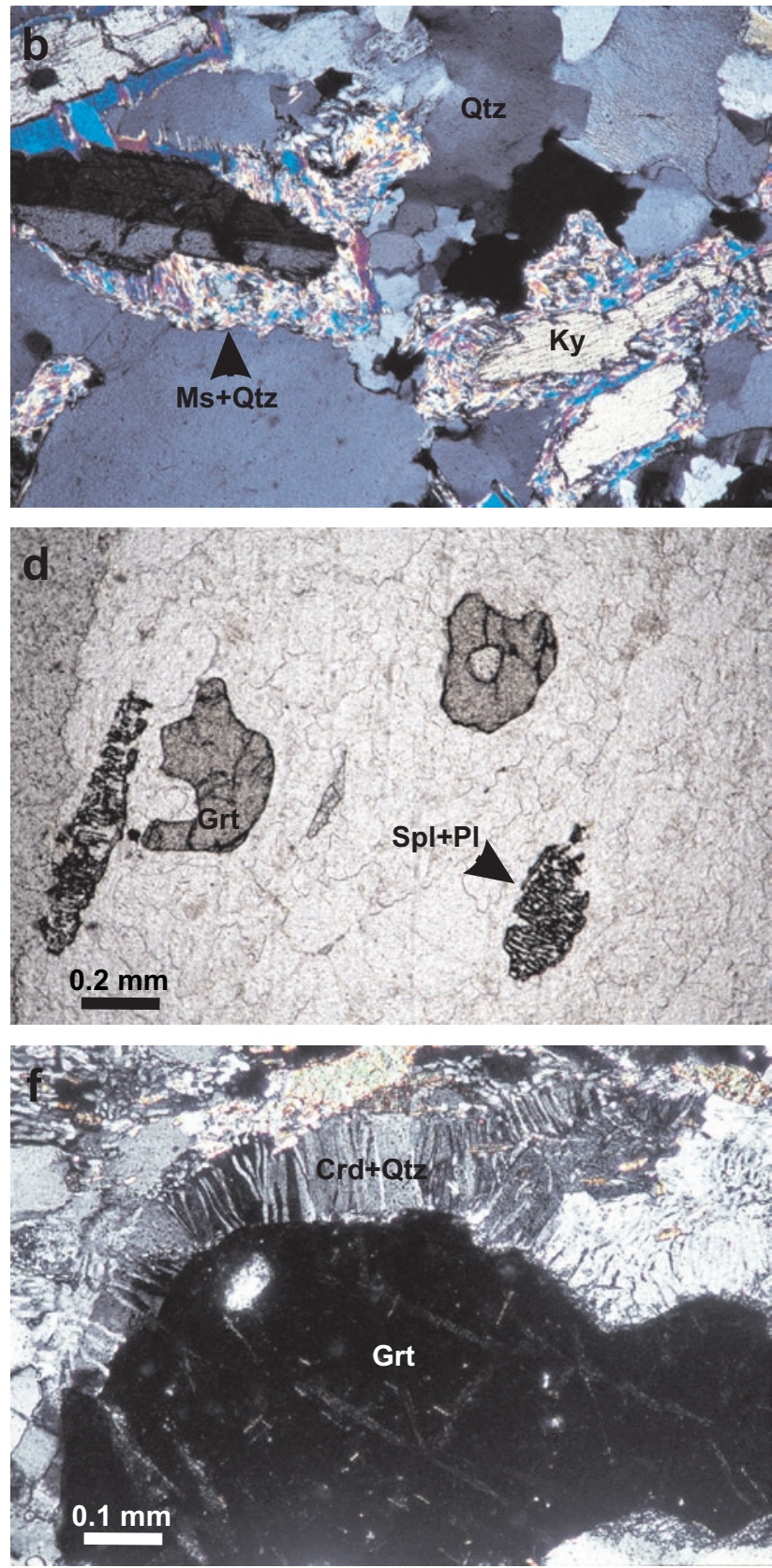

Fig. 4 Photomicrographs of reaction textures in granulites. a - biotite forming at the expense of garnet, PPL, leucogranulite, disused quarry in Stráž nad Ohří, Ohře Crystalline Complex. b - muscovite and quartz replacing kyanite, leucogranulite, XPL, Mikulovice, Ohře Crystalline Complex. c - kyanite transformed into sillimanite, PPL, leucogranulite, Plešovice quarry, Blanský les Massif. d - spinel and plagioclase forming at the expense of kyanite, PPL, leucogranulite, Pod Libínem quarry, Prachatice Massif. e - orthopyroxene and plagioclase symplectite completely replacing garnet, surrounded by plagioclase and hornblende mosaic, PPL, mafic granulite, borehole LV-1, S of Lišov, Lišov Granulite Massif. f - cordierite and quartz corona around garnet, XPL, leucogranulite, Pod Libínem quarry, Prachatice Massif. 

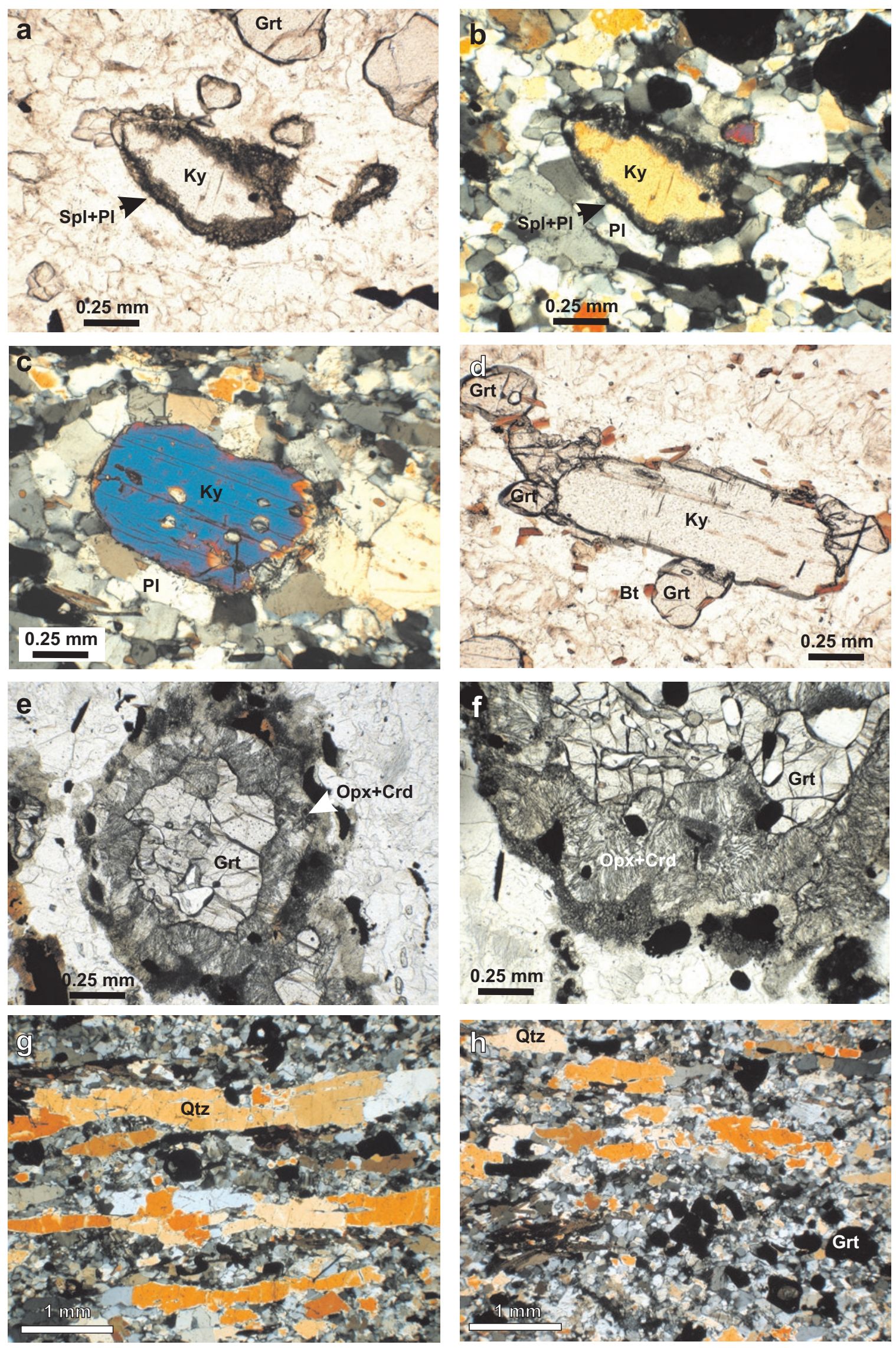


\subsection{Deformation}

Similar to their complex metamorphic history, felsic granulites record evidence of polyphase deformation. Amphibolite-facies assemblages of biotite \pm sillimanite and recrystallized quartz and feldspars fabrics (foliation and lineation) formed in high-strain domains, where deformation presumably facilitated rehydration and retrogression (producing granulite gneisses). The original HP-HT assemblages have to be looked for in rarely preserved low-strain domains where the rocks escaped this pervasive deformation. Major parts of the felsic granulite bodies have largely metamorphic fabrics ranging from elongate granoblastic and porphyroclastic to mylonitic (Figs 3e, $5 g-h$ ), resulting from relatively HT progressive deformation and successive dynamic recrystallization (see e.g. Kodym 1972; Behr 1978; Vrána and Jakeš 1982; Vrána 1989; Kotková and Harley 1999). Recent microstructural studies have distinguished 2-3 deformation stages: (i) relict granulite-facies fabrics $\mathrm{S}_{1}$, defined by compositional banding of monomineralic coarse quartz bands and fine-grained feldspars, (ii) granulite-facies fabrics $S_{2}$, with quartz ribbons progressively recrystallized into an equigranular matrix, and local mineral lineation defined by quartz (and sporadic biotite?), and (iii) amphibolite-facies fabrics $\mathrm{S}_{3}$, defined by alignment of biotite (and sillimanite), biotite-rich and biotite-poor bands and preferred orientation of quartz and feldspar (Kotková 1993, Svojtka et al. 2002 - albeit attributing the development of quartz ribbons to the amphibolite stage; Franěk et al. 2006).

\subsection{Major-element zoning in garnet}

In felsic granulites, garnets of almandine-rich composition (up to $c$. $80 \% \mathrm{Alm}$ ) of up to $1 \mathrm{~mm}$ in size represent the single peak $\mathrm{Fe}-\mathrm{Mg}$-bearing phase. These garnets usually have flat compositional profiles in their cores, typical of high-grade garnets where growth zoning has been obliterated by volume diffusion. They potentially preserve high Ca contents in their cores (c. 5-12 mol. \% in the most acid but reaching up to $c$. $20 \mathrm{~mol}$. \% in more granodioritic compositions), reflecting high-pressure granulite conditions. Major-element zoning in primary

$\Leftarrow$

Fig. 5 Photomicrographs of reaction textures and deformational fabrics in granulites. Leucogranulite, Zrcadlová hut' quarry, Blanský les Massif $\mathbf{a}, \mathbf{b}$ - spinel and plagioclase corona on kyanite isolated from the surrounding matrix by a plagioclase moat, PPL and XPL. c - kyanite surrounded by plagioclase corona, XPL. d - Grt II corona on kyanite, PPL. Strongly peraluminous granulite clast in the Viséan conglomerates, Luleč Quarry, Drahany Uplands e, f - orthopyroxene and cordierite corona around garnet, finer and coarser-grained, PPL. Leucogranulite, Kobyli hora quarry, Prachatice Massif , g, h - quartz ribbons and platy quartz, XPL. garnet (Fig. 6) reflects operation of the post-peak reactions described under 7.1. Garnet rims are depleted in $\mathrm{Ca}$ and their $\mathrm{Mg} /(\mathrm{Mg}+\mathrm{Fe})$ ratios are lower than in the cores - the latter being more obvious when retrograde biotite is present. These features are attributed to decompression (GASP reaction) and post-peak cooling (diffusional re-equilibration). Garnets of garnet-pyroxene granulites have higher $\mathrm{Ca}$ and lower $\mathrm{Fe}$ contents controlled by the whole-rock composition; the character of zoning is nevertheless similar to that of the felsic granulites. For further details on garnet composition and zoning description and interpretation see Vrána (1989), Carswell and O’Brien (1993), Kotková (1993), Kotková and Harley (1999), O’Brien (1999), Cooke et al. (2000) and O’Brien (2006).

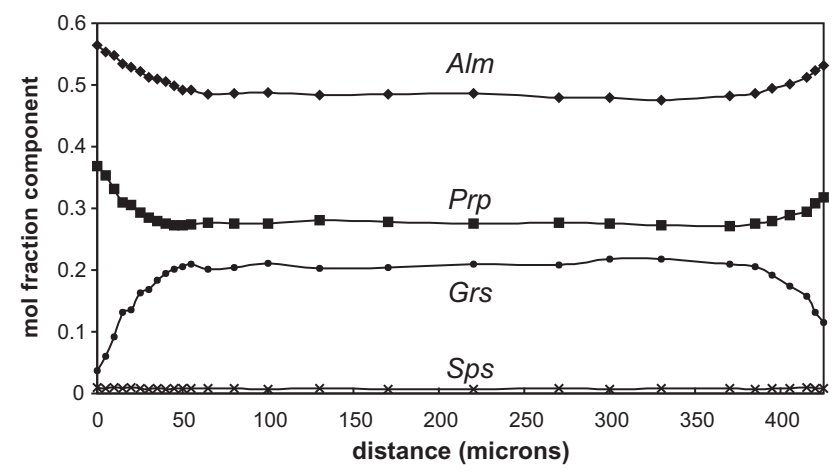

Fig. 6 Garnet zoning, leucogranulite, Zrcadlová hut' quarry, Blanský les Massif. Whole rock contains $71 \% \mathrm{SiO}_{2}$.

In rare cases, felsic granulites also contain a second garnet generation. Smaller garnets, disseminated or forming trails in the quartzo-feldspathic matrix in granulites of the Ohře Crystalline Complex (Kotková 1993), have lower $\mathrm{Ca}$ and $\mathrm{Mg} /(\mathrm{Mg}+\mathrm{Fe})$ compared to the primary Grt I rims. In Moldanubian granulites, a similar type of garnets occurs (Kotková and Harley 1999). In addition, garnet coronas form around kyanite breakdown products in Ca-rich domains (O’Brien 1999; Owen and Dostal 1996a). In contrast to the primary garnets, containing inclusions of mesoperthite and kyanite, phases belonging to the HP-HT granulite assemblage, and exsolved rutile needles, these secondary garnets contain relics of corundum, spinel or even sapphirine, and they have higher Ca contents and lower $\mathrm{Mg} /(\mathrm{Mg}+\mathrm{Fe}$ ) ratios (see also summary of O’Brien 2006).

Intermediate to mafic and $\mathrm{Al}-\mathrm{Fe}-\mathrm{Mg}$-rich rocks allow for more robust $\mathrm{P}-\mathrm{T}$ determination and derivation of a part of the $\mathrm{P}-\mathrm{T}$ path from garnet zoning. The extent of decompression can be quantified using garnet core and rim compositions combined with appropriate peak and decompression-related coexisting minerals. In the pyropic garnetite, for instance, a marked decrease in 
$\mathrm{Mg} /(\mathrm{Mg}+\mathrm{Fe})$ ratio within $\sim 100 \mu \mathrm{m}$ of the garnet grain margin, reflecting several successive garnet-breakdown reactions resulting in complex symplectite formation, can be interpreted as a result of significant decompression using petrogenetic grid for the FMAS system (Kotková et al. 1997).

\subsection{Medium- and low-pressure overprint of the high-pressure granulite assemblages}

The decompressional reactions described above produce mineral assemblages corresponding to medium-pressure (MP) granulite metamorphism. This is characterized by coexistence of orthopyroxene and plagioclase in mafic rocks. Formation of plagioclase coronas around metastable kyanite and kyanite transformation into sillimanite is typical of felsic rocks. Spinel-plagioclase (and sapphirine-plagioclase) aggregates replacing aluminosilicate in felsic and Al-rich granulites are confined to the sillimanite-stability field, too (O'Brien 1999; Rötzler and Romer 2001). Cordierite and orthopyroxene \pm sapphirine \pm spinel coexist in $\mathrm{Al}-\mathrm{Fe}-\mathrm{Mg}$-rich compositions.

Kyanite consumption by hercynitic spinel and development of the Pl moats and Grt II coronas around it attest to operation of $\mathrm{Fe}, \mathrm{Mg}$ and $\mathrm{Ca}$ diffusion. Formation of the plagioclase coronas around kyanite (Fig. 5c) has been explained by diffusional transfer of $\mathrm{Ca}$ and $\mathrm{Na}$ (being more mobile than $\mathrm{Si}$ and $\mathrm{Al}$ ) from the surrounding matrix (Tajčmanová et al. 2006b). Within the resulting isolated Si-undersaturated domain, spinel and even corundum can subsequently crystallize. Highly mobile Fe needed for the formation of the hercynitic spinel after kyanite could come from a former biotite replacing garnet (Tajčmanová et al. loc. cit.).

Pressure estimates for this MP stage range mostly between 6 and 8 kbar for granulites in the Moldanubian Zone (Tab. 1), whereas estimated temperatures show much larger range between 650 and $900^{\circ} \mathrm{C}$. Higher temperature estimates from this interval relate to the GrtCpx-bearing granulites and pyropic garnetite. Temperatures within the lower part of this interval can represent continued Fe-Mg exchange during post-decompressional cooling or even blocking temperatures for this exchange during the cooling history of these rocks (Carswell and O’Brien 1993; Cooke and O’Brien 2001).

Rare garnet-bearing mafic granulites of the Lišov Massif record high peak P-T conditions and a HT-MP overprint (Kotková 1998a, b, see Tab. 1). However, both the predominant felsic granulites (with low-Ca garnet and lacking aluminosilicate) and two-pyroxene granulites of tonalitic-quartz dioritic composition and charnockites of the Lišov Massif (with highly annealed equilibrium mosaic fabrics and homogeneous core-rim mineral compositions) are free of HP relics and show only MP record
(Janoušek et al. 2006b). Poikilitic clinopyroxene and Carich plagioclase cores considered as primary magmatic feature, absence of any relics of decompressional coronas and stability of Opx suggesting low $\mathrm{f}\left(\mathrm{H}_{2} \mathrm{O}\right)$ in the lowerpressure rocks were taken as evidence for the initial equilibration/crystallization of the rocks at mid-crustal levels. The garnet-bearing HP mafic granulites would therefore represent a foreign component in the Lišov Massif (Janoušek et al. 2006b). Alternatively, equilibrium annealed mosaic just next to the decompressional reaction textures in the HP relict mafic granulite assemblages (Fig. 4e) suggests that an extensive MP-LP overprint could have obliterated completely any HP-related or decompressional features (Kotková 1998b).

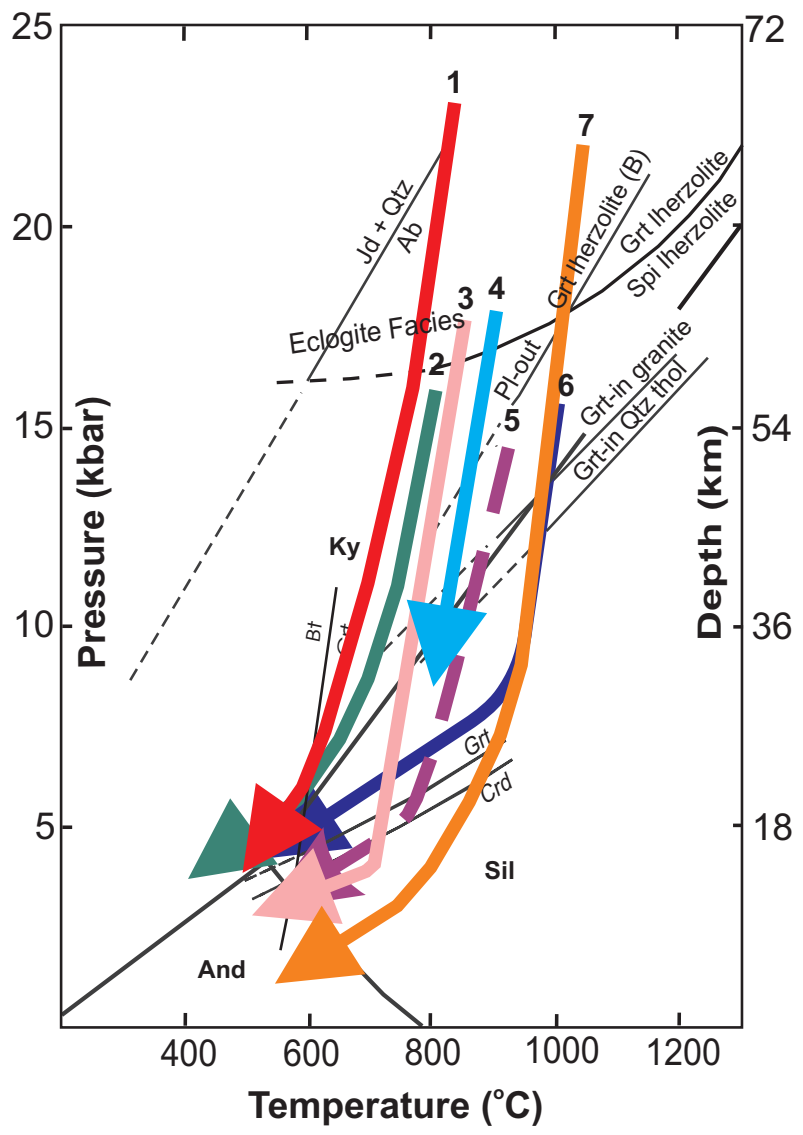

Fig. 7 Synoptic diagram showing $\mathrm{P}-\mathrm{T}$ paths of the HP granulites of the Bohemian Massif. 1 - Erzgebirge (Willner et al. 1997), 2 - Ohře Crystalline Complex (Kotková 1993; Kotková et al. 1996), 3 - Strážek Unit (Tajčmanová et al. 2006a), 4 - Sowie Gory and Snieznik (Kryza et al. 1996; O’Brien et al. 1997), 5 - South Bohemian granulites (Vrána 1992b; Kotková and Harley 1999), 6 - granulites of the Lower Austria (Carswell and O’Brien 1993), 7 - Saxonian granulites (Rötzler and Romer 2001). Position of reactions - references: Ab $=\mathrm{Jd}+\mathrm{Qtz}$ (Holland 1980); Grt- in and Pl-out for quartz tholeiites and Grt + Cpx $=\mathrm{Opx}+\mathrm{Pl}$ (Green and Ringwood 1967); Grt-in for granite compositions (Green and Lambert 1965); garnet lherzolite = spinel lherzolite (O’Hara et al. 1971). 


\subsection{Post-decompressional cooling}

Hydration reactions, especially muscovite formation at the expense of kyanite, and transformation of sillimanite to andalusite are clearly related to cooling of the rocks. Important indications of the cooling are represented by garnet coronas forming around plagioclase (anorthite) and spinel aggregates (Fig. 3f). Their formation implies recrossing of the pressure-dependent reactions like GASP in felsic or $\mathrm{An}+\mathrm{Spl}+\mathrm{Opx}=$ Grt in mafic granulites, which is indicative of near-isobaric cooling. The P-T conditions of formation of these coronas were estimated at $>7 \mathrm{kbar}$ for any temperature above $750^{\circ} \mathrm{C}$ and arbitrary feldspar composition (O’Brien 1999). Alternatively, the pressures could have been as low as $\sim 2-3 \mathrm{kbar}$ at $c$. $750{ }^{\circ} \mathrm{C}$ (Owen and Dostal 1996a).

\section{P-T paths and exhumation of granulite complexes}

\subsection{P-T paths}

A synoptic diagram showing published $\mathrm{P}-\mathrm{T}$ paths for granulites of the Bohemian Massif shows that prograde P-T paths are usually not preserved (Fig. 7). This is the result of rapid reaction kinetics at HT recorded by the granulites, due to which early phases were mostly consumed and growth garnet zoning (when present) largely erased by volume diffusion. However, some examples of preserved prograde garnet zoning have been described, for instance from mafic pyroxene-bearing granulites in the Lower Austria (Cooke et al. 2000 and references therein). Its preservation requires short residence times at the documented high temperatures of $c \cdot 1000^{\circ} \mathrm{C}$, rapid exhumation and cooling, in addition to the lack of an intergranular fluid phase (Cooke et al. loc. cit.).

Evidence of prograde evolution has been reported from the Erzgebirge granulite-facies metasediments, with estimated peak $\mathrm{T}$ of up to $\sim 800^{\circ} \mathrm{C}$ and a "cold" exhumation path. These rocks contain phengite inclusions in garnet indicative of near-to-isobaric heating by $c .180^{\circ} \mathrm{C}$ at $c$. 14 kbar (Willner et al. 1997; Massonne 2006).

The sequence of mineral assemblages and $\mathrm{P}-\mathrm{T}$ estimates provide evidence for granulite exhumation along a clockwise $\mathrm{P}-\mathrm{T}$ path. Figure 7 shows that $\mathrm{P}-\mathrm{T}$ paths of the HP Bohemian granulites are dominated by initial near-to-isothermal decompression. This itself is a sign of a rapid exhumation of the rocks. Subsequent near-toisobaric cooling is more evident on the "hot" $\mathrm{P}-\mathrm{T}$ paths, passing through sillimanite and even cordierite stability field, as characteristic of the Moldanubian granulite massifs. Contrasting "cold" P-T path, i.e. absence of MP-HT overprints, has been first reported for granulites of the Ohře Crystalline Complex (Kotková 1993; 1995; Kotková et al. 1996).

\subsection{Zircon geochronometry - peak $P-T$ conditions or not?}

Dating of accessory zircon and monazite provides constraints on the absolute age of granulite formation and high-T evolution. Conventional single- and multigrain $\mathrm{U}-\mathrm{Pb}$, SHRIMP and single zircon evaporation dating, as well as Th- $\mathrm{U}-\mathrm{Pb}$ monazite dating of $\mathrm{BM}$ granulites, yield consistent data clustering mostly at $c$. $340 \mathrm{Ma}$ (except Góry Sowie granulites - for review see O'Brien and Rötzler 2003; Janoušek and Holub 2007 and Tab. 2). Clear, multifaceted, spherical and equant zircon grains, mostly without any older cores, have characteristics of zircons from high-grade metamorphic terranes (Pidgeon and Bowes 1972; "metamorphic" zircons in further text). This was noted already in the pioneering study by van Breemen et al. (1982), which also showed that Rb-Sr whole-rock dating of BM granulites (yielding 486 and $431 \mathrm{Ma}$, Arnold and Scharbert 1973) is unsuitable for timing the granulite-facies metamorphism. As pointed out by Vielzeuf and Pin (1989), the data of van Breemen et al. (1982) and later Aftalion et al. (1989) indicated a HP event in the Bohemian Massif significantly younger than that of early Palaeozoic age (c. 430-400), documented in the Variscan massifs in France and Spain.

The significance of the $340 \mathrm{Ma}$ ages has been a matter of debate. These ages were interpreted as either dating the peak HT-HP granulite formation event or the MP granulite overprint associated with melting during their uplift to mid-crustal levels. Indeed, it is not always straightforward to link the age to a certain pressure (depth) as the chronometers are temperature-dependent, relating to closure temperatures in accessory phases. The solution to this problem can be provided by (i) careful studies of textural relationships between accessory phases and mineral assemblages giving information on pressure, (ii) studies of internal zircon structure and age determinations in-situ, and (iii) dating of other HP phases such as titanite. Arguments cited in the literature in favour of the $c$. $340 \mathrm{Ma}$ age being related to the HP event are:

- presence of spherical zircon inclusions in phases of the HP stage (garnet and ternary feldspar in felsic granulites, garnet and clinopyroxene in mafic granulites; e.g. O’Brien et al. 1997; Kröner et al. 2000; Romer and Rötzler 2001),

- large euhedral zircons dated at 338 Ma enclosed in high-pressure garnet in Zr-rich hyperpotassic granulite formed by HP dry melting (Vrána 1989; Aftalion et al. 1989). These zircons have been recently proposed as a potential reference material for in-situ isotopic analyses (Sláma et al. 2006), 
Tab. 2 Overview of the U-Pb (Pb-Pb) and Sm-Nd geochronological data for HP granulites of the Bohemian Massif.

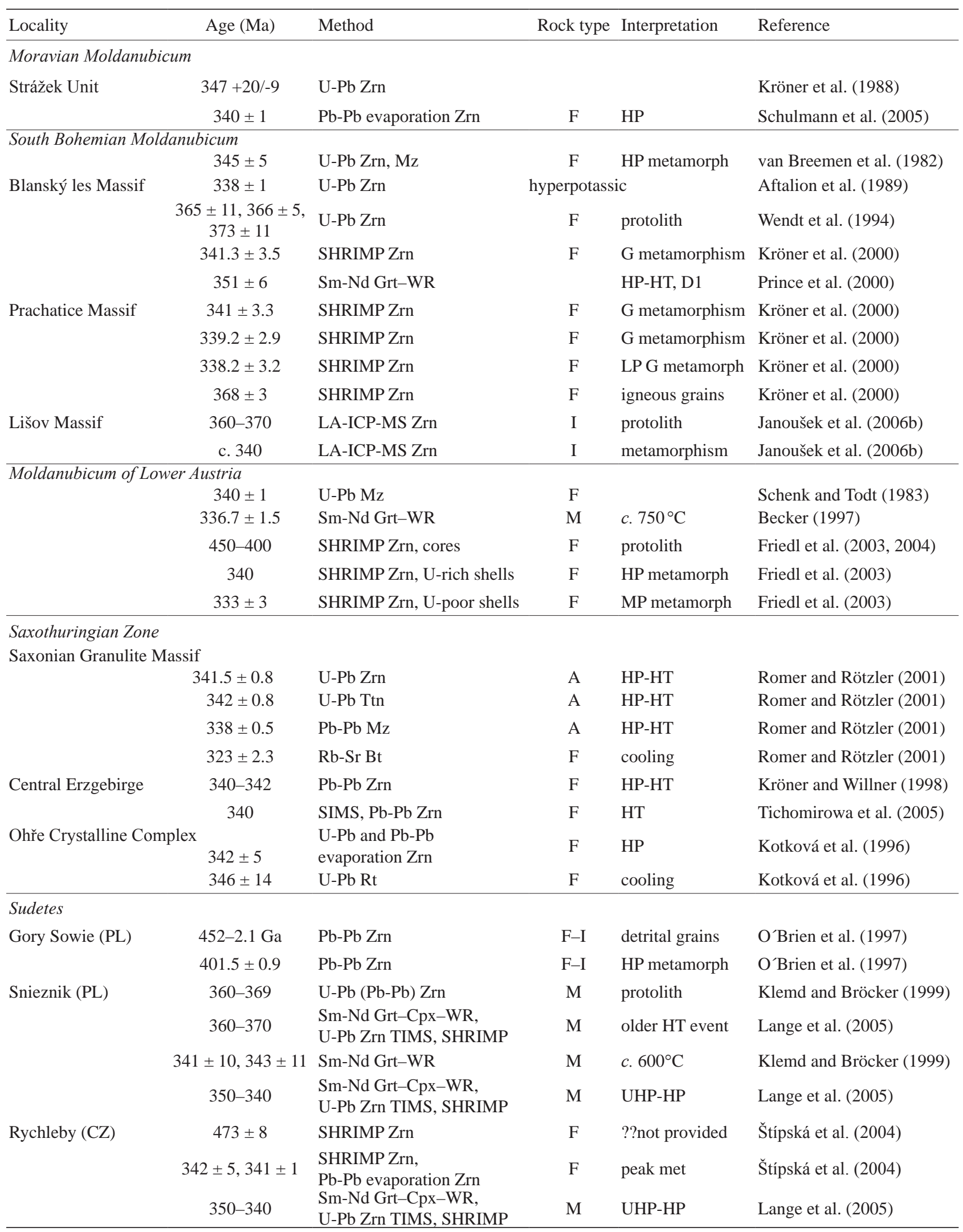

For legend see Tab. 1 
- the hyperpotassic granulite zircon typology similar to zircons from peralkaline granites and syenites of supposedly mantle origin, having crystallized from hot and dry magma (Vrána 1989),

- presence of zircon dated at $c$. 341 Ma with prograde pargasite and phengite inclusions in high-grossular garnet in felsic granulite; this age was interpreted as dating the metamorphic zircon growth on the prograde path, approaching the thermal peak at elevated $\mathrm{P}$ (Kröner and Willner 1998),

- SHRIMP dating of both separated and in-situ zircons with known petrographic position yielded identical ages of c. 340 Ma for the HP, MP and LP granulite stage (Kröner et al. 2000),

- titanite from the HP-HT assemblage yielded age identical to zircon within error (Romer and Rötzler 2001),

- textural and isotopic evidence of $c .333$ Ma medium-pressure granulite-facies event from textural and isotopic data for Moldanubian granulites (SHRIMP zircon, Friedl et al. 2003) and granulite pebbles in Viséan conglomerates (monazite II, Kotková et al. in press - see Chapter 8.3.6)

- correspondence of the $\mathrm{U}-\mathrm{Pb}(\mathrm{Pb}-\mathrm{Pb})$ zircon ages for granulites and $\mathrm{Sm}-\mathrm{Nd}$ ages for garnet peridotites (e.g. O’Brien et al. 1997; Becker 1997; Medaris et al. 2005 and references therein).

Zircon crystallization during the granulite exhumation at medium pressures was suggested by Roberts and Finger (1997). They proposed that under the conditions of $1000^{\circ} \mathrm{C}$ and 16 kbar estimated for HP felsic granulites of the $\mathrm{BM}$, there should have been peraluminous melt present with such a high solubility of $\mathrm{Zr}$, that zircon should have been dissolving rather than crystallizing. Zircon crystallization would take place later, during exhumation at lower temperatures when the $\mathrm{Zr}$ saturation of the melt was reached - or along a different "colder" $\mathrm{P}-\mathrm{T}$ path. As mentioned also by Tichomirowa et al. (2005), Zr solubility can decrease due to a change in the melt composition as a result of mineral crystallization, and therefore zircon crystallization does not have to occur at the peak P-T conditions. Tropper et al. (2005) saw indirect evidence supporting decompressional zircon crystallization in the rutile-melt relationships in their experimental results. As almost no rutile crystallized at experimental runs at $\mathrm{T}>900{ }^{\circ} \mathrm{C}$ and $\mathrm{Ti}$ is partitioned between garnet and melt, they assumed that large rutile grains typical of the Bohemian leucogranulites could crystallize after the peak $\mathrm{P}-\mathrm{T}$ conditions, the same way as zircon.

The paper of Roberts and Finger (1997) was inspired by the presence of oscillatory zoning in one or more outer growth shells of zircon described from felsic granulites. However, these growth shells were later interpreted as representing both granulite-facies zircon growth at (or close to) peak P-T conditions at $340 \mathrm{Ma}$ (U-rich shells) and during medium-pressure overprint at $333 \mathrm{Ma}$ (U-poor shells) in the presence of melt (SHRIMP, Friedl et al. 2003). Tichomirowa et al. (2005) though attributed dark (CL) U-rich zircon rims from granulite gneisses in Central Erzgebirge dated at $340 \mathrm{Ma}$ rather to solid-state recrystallization and just in few cases to new zircon crystallization from the melt at unknown pressure. Taking into account also the evidence listed above, it therefore seems that zircon did crystallize at, or close to, the peak conditions, too.

\subsection{Thermochronology, cooling and exhumation rates for granulites}

The age determination of several different mineral phases with variable closure temperatures of the isotope system(s) provides information on $T$ - $t$ (temperature-time) history of the rock and the cooling rate. Most published closure temperatures for different geochronometers however only apply for moderate to slow cooling rates. Temperature of isotopic closure tends to increase at higher cooling rate (Dodson 1973) or in dry systems (Becker 1997; Romer and Rötzler 2001). To better constrain the exhumation rate of the granulite massifs, the age data should be linked to reliable pressure estimates (i.e. $P-T-t$ path). Additional incorporation of the structural data permits interpretation of the so-called P-T-t-d path. Several examples from the BM using this approach are discussed below.

\subsubsection{Ohře (Eger) Crystalline Complex (OCC)}

The $\mathrm{U}-\mathrm{Pb}$ and $\mathrm{Pb}-\mathrm{Pb}$ evaporation dating of multifaceted metamorphic zircons from felsic granulites of the Ohře Crystalline Complex yielded $348 \pm 10$ (upper intercept, U. I.) and $339 \pm 1 \mathrm{Ma}$, respectively. These ages were attributed to the peak P-T conditions of 15-17 kbar and at least $830^{\circ} \mathrm{C}$. The slightly discordant $\mathrm{U}-\mathrm{Pb}$ age of rutile corresponds to $346 \pm 14 \mathrm{Ma}$. Overlap of the zircon and rutile ages with contrasting closure temperatures for $\mathrm{U}-\mathrm{Pb}$ system suggests rapid cooling - and exhumation - of the rocks (Kotková et al. 1996). The U-Pb monazite age of $342 \pm 1$ for the associated orthogneisses is identical within the error with the age of granulite zircon. This age and $\mathrm{Ar}-\mathrm{Ar}$ plateau age of muscovite from the orthogneisses (341 $\pm 4 \mathrm{Ma}$ ), along with the closure temperature for $\mathrm{U}-\mathrm{Pb}$ in monazite and for $\mathrm{K}-\mathrm{Ar}$ in muscovite, were used to calculate the cooling rate of $c .50+25 /-17^{\circ} \mathrm{C}$ $\mathrm{Myr}^{-1}$. The rocks of the OCC preserve high-energy lobate quartz-feldspar grain boundaries (Fig. 3c) related to HT diffusional creep and the HP-related mineralogy does not show any MP-HT overprint. Both of these aspects reflect high cooling and exhumation rates (Zulauf et al. 2002). 


\subsubsection{Central Erzgebirge}

Quartzofeldspathic crustal rocks of the Central Erzgebirge preserve HP-HT mineral assemblages recording peak $\mathrm{P}-\mathrm{T}$ conditions of up to $22 \mathrm{kbar}$ and $830^{\circ} \mathrm{C}$. Similar to the OCC, the rocks have not experienced any MP-HT overprint on their exhumation-related $\mathrm{P}-\mathrm{T}$ path (Willner et al. 1997). Multifaceted metamorphic zircons from Grt-Ky-bearing felsic granulite show well-developed sector zoning (compare Kröner et al. 2000 below) and yielded $\mathrm{Pb}-\mathrm{Pb}$ evaporation ages of $c .341( \pm 0.5) \mathrm{Ma}$ (Kröner and Willner 1998) interpreted as dating the peak P-T conditions. Numerous Ar-Ar data on white mica and hornblende in the rocks of the granulite-bearing Gneiss-Eclogite Unit (GEU) and the overlying units yielded plateau ages of $c .338 \mathrm{Ma}$, suggesting very high exhumation rate. This was calculated at at least $4 \mathrm{~mm} / \mathrm{yr}$ (see Willner et al. 1997 and references therein). Extensive structural studies enabled successive deformation stages to be defined and the reconstruction of the $\mathrm{P}-\mathrm{T}-\mathrm{t}-\mathrm{d}$ paths of the GEU and other tectonometamorphic units in the Erzgebirge (Willner et al. 2000). Their interpretations as well as results of the numerical modelling of the P-T paths are presented in Chapter 10.

\subsubsection{Moldanubian Zone of southern Bohemia and Lower Austria}

Becker (1997) estimated cooling rate of felsic granulites in Lower Austria at min. $25^{\circ} \mathrm{C} / \mathrm{Myr}$ and max. $150^{\circ} \mathrm{C} / \mathrm{Myr}$ based on the U-Pb monazite age (340 $\pm 1 \mathrm{Ma}$, Schenk and Todt 1983), his Sm-Nd garnet-WR age (336.7 \pm $1.5 \mathrm{Ma}$ ) and the closure temperatures of $c .750^{\circ} \mathrm{C}$ and $600^{\circ} \mathrm{C}$ for the respective geochronometers of Mezger (1990). O’Brien (1999) documented the presence of asymmetric garnet zoning in felsic granulites with $X_{\mathrm{Mg}}$ strongly decreasing towards biotite-bearing domains, but slightly higher than in the cores at the opposite, garnet side. This implies that grain-boundary diffusion was in this case as slow as volume diffusion and not extremely fast as postulated in diffusion models. O’Brien (1999) suggested that neglecting this can result in too fast cooling rates or too old extrapolated ages based on closure temperature models.

Three HT stages significantly differing in pressure were distinguished in the felsic and intermediate to mafic granulites of the south Bohemian Moldanubicum: HTHP stage (> $15 \mathrm{kbar},>900^{\circ} \mathrm{C}$ ), HT-MP stage (6-8 kbar, 700-800 ${ }^{\circ} \mathrm{C}$ ) and HT-LP (c. 4 kbar) (see Tab. 1). SHRIMP single-grain dating of zircon separated from the samples as well as in-situ analyses of grains with known petrographic position was performed by Kröner et al. (2000). Spherical metamorphic and short prismatic grains from granulites (HP, MP) and the cordierite-bearing melt patch
(LP) were all concordant and yielded indistinguishable results producing an average age of $339.8 \pm 2.6 \mathrm{Ma}$. The three HT stages therefore occurred within the time scale of the error of the SHRIMP analysis suggesting very high exhumation rate (Kröner et al. 2000).

\subsubsection{Saxonian Granulite Massif}

Combined P-T and geochronological studies of the Saxonian granulite samples - (i) sapphirine-bearing $\mathrm{Al}-\mathrm{Mg}-\mathrm{Fe}-\mathrm{rich}$ granulite, (ii) retrogressed biotite-bearing felsic granulite and (iii) garnet-clinopyroxene-titanitebearing granulite - were carried out by Rötzler and Romer (2001) and Romer and Rötzler (2001). (i) The best-constrained age estimate of six concordant multifaceted metamorphic zircons was the weighted $\mathrm{U}-\mathrm{Pb}$ age of $341 \pm 0.8$ Ma. Discordant monazites yielded a minimum weighted $\mathrm{Pb}-\mathrm{Pb}$ age of $338 \pm 0.5 \mathrm{Ma}$. The $\mathrm{U}-\mathrm{Pb}$ ages of rutile ranged between $320 \pm 4$ and $345 \pm 4$ Ma. Four apatite samples had contrasting $\mathrm{U}-\mathrm{Pb}$ ages ranging between 272 and 330 Ma. (ii) Two biotite and one alkali feldspar samples define a common $\mathrm{Rb}-\mathrm{Sr}$ isochron corresponding to the age of $323 \pm 2.3 \mathrm{Ma}$. (iii) The $\mathrm{U}-\mathrm{Pb}$ age of 342 $\pm 0.8 \mathrm{Ma}$ was considered to be the best age estimate for titanite. Zircon and titanite gave ages identical within error, which is considered to date the peak P-T conditions of $>1000{ }^{\circ} \mathrm{C}$ and $\sim 22 \mathrm{kbar}$ and to demonstrate that the closure temperatures of zircon (present also as inherited grains in the peak garnet) as well as titanite in dry systems exceed $1000^{\circ} \mathrm{C}$. Combination of the age data and the $\mathrm{P}-\mathrm{T}$ path show that the Saxonian Granulite Massif was exhumed to mid-upper crustal levels at a fast average rate of $>9-18 \mathrm{~mm} / \mathrm{yr}$, which subsequently slowed down to $<2 \mathrm{~mm} / \mathrm{yr}$. The initial cooling rate was estimated at $25-50{ }^{\circ} \mathrm{C} / \mathrm{Myr}$ from the age difference between zircon and monazite.

\subsubsection{Sudetes - Rychleby Mts.}

The peak $\mathrm{P}-\mathrm{T}$ stage for the omphacite-bearing granulites of the Rychleby Mts. was estimated at c. $18 \mathrm{kbar}$ and $c$. $900^{\circ} \mathrm{C}$. The U-Pb SHRIMP and $\mathrm{Pb}-\mathrm{Pb}$ evaporation zircon ages corresponding to $342 \pm 5$ and $341.4 \pm 0.7$ Ma were attributed to the peak P-T conditions (Štípská et al. 2004). These ages overlap within error with those for a syntectonic granodiorite sill (345-339 Ma), emplaced during thrusting. If the depth of granodiorite emplacement was c. $25 \mathrm{~km}$, a high exhumation rate of 3 or even $15 \mathrm{~mm} / \mathrm{yr}$ (including and not including the error of the age data) for granulite exhumation from $c .70 \mathrm{~km}$ to $c .35 \mathrm{~km}$ depth (amphibolite-facies overprint) was calculated. Further uplift along a magma-lubricated shear zone proceeded at $24-40 \mathrm{~mm} / \mathrm{yr}$, as estimated from the time needed for solidification of granodioritic magma (c. 250000 years) 
and the difference between thrusting depth and assumed depth of the magma emplacement (Štípská et al. 2004). High cooling rates of $20-100^{\circ} \mathrm{C} / \mathrm{Myr}$ were calculated for the initial exhumation from the temperature difference between the peak and the retrogressive conditions, related to the granodiorite emplacement.

\subsubsection{Viséan conglomerates}

Granulite clast assemblage with distinct lithology and petrology compared to the Moldanubian granulites occurs in the late Viséan conglomerates at the eastern margin of the Bohemian Massif. Spherical multifaceted metamorphic as well as prismatic zircons from felsic to intermediate granulite compositions are concordant to slightly discordant, giving closely clustering ${ }^{206} \mathrm{~Pb} /{ }^{238} \mathrm{U}$ ages of $337 \pm 1$ to $339 \pm 1.6 \mathrm{Ma}$. These ages were considered as dating high-pressure granulite metamorphism at min. $12 \mathrm{kbar}$ and $820^{\circ} \mathrm{C}$. The extensive medium-pressure/high-temperature overprint of granulite assemblages $\left(6 \pm 1 \mathrm{kbar}, 820^{\circ} \mathrm{C}\right)$ has been dated at $\sim 333 \mathrm{Ma}$ by U-Pb in monazite, associated with the Opx-Crd symplectite around garnet. The youngest rutile age corresponded to $\sim 337$ Ma. Thermochronology and derived P-T path of the source units of granulite pebbles reflect two-stage exhumation of the granulites. Near-to-isothermal decompression from at least $44 \mathrm{~km}$ to mid-crustal depths of $\sim 22 \mathrm{~km}$ was followed by near-isobaric cooling stage, with cooling rate $\geq 120^{\circ} \mathrm{C} / \mathrm{Myr}$. Minimum average rate of exhumation from maximum estimated depth to the surface was calculated at at least 3-4 mm/yr, as derived from the geochronological data and known age of the conglomerate deposition in the Upper Viséan at $326 \pm 2$ Ma (Kotková et al. in press).

\section{Granulite protoliths}

Predominant felsic granulites of the BM were formerly interpreted as regionally metamorphosed (tuffaceous) acid volcanic rocks with pelitic admixture (Suess 1926; Zoubek 1946, 1988), based on their supposed stratigraphic position. Other authors considered the granulites as former migmatites (Kodym 1972; Kodym et al. 1978), or metasediments (e.g. Scharbert 1964).

Information on the granulite protoliths can be derived from (i) structures and relationships related to the (pre)peak conditions - however, these are scarcely preserved in the felsic granulites of the BM. As leucogranulites typically show largely recrystallized metamorphic fabrics due to post-peak deformation and recrystallization, it is then only (ii) whole-rock composition (including radiogenic isotopes) and (iii) mineral geochemistry, along with (iv) internal structure and dating of petrogenetically im- portant minerals like zircon, which provide evidence for early processes of formation of these rocks. (v) Melting experiments on specific starting materials over the range of the estimated granulite peak $\mathrm{P}-\mathrm{T}$ conditions have been performed recently.

\subsection{Structures and relationships related to the (pre)-peak conditions}

Garnet-bearing hypersolvus leucogranite from the Lišov Massif and hypersolvus hyperpotassic granulite from the Blanský les Massif (both within the south Bohemian Moldanubicum) represent examples of granulite rock types with preserved peak-related structures and/or specific bulk composition. They were interpreted as products of melting and crystallization at HP (lower crustal/upper mantle) conditions (Vrána and Jakeš 1982; Vrána 1989). The garnet-bearing hypersolvus leucogranite contains preserved mesoperthite, garnet, relict titanomagnetite with unmixed ilmenite and granular mosaic of equidimensional quartz. The garnet-bearing hyperpotassic granulite, rich in zircon, has a syenitic composition similar to that resulting from HP dry melting experiments on the granite system. See Vrána (1989), Kotková and Harley (1999) and Tropper et al. (2005) for references of relevant experimental works.

\subsection{Whole- rock composition and mineral geochemistry}

The idea of HP melting was pursued by Jakeš (1997) and Kotková and Harley (1999). While Jakeš used whole-rock chemical data of selected felsic granulites of the south Bohemian Moldanubicum to demonstrate that they are pristine dehydration melts, the latter authors studied major and trace element composition of garnets and the distribution of trace elements, especially rare earth elements (REE), between garnet and accessory phases (apatite and zircon) in the leucogranulites. This approach combined petrography and geochemistry to assess the relationships between major and accessory minerals and thereby to evaluate the rock petrogenesis. Others have utilised large whole-rock geochemical data sets to constrain granulite petrogenesis (Fiala et al. 1987; Vellmer 1992; Janoušek et al. 2004).

Whole-rock geochemical characteristics of the granulites are summarized below. Data sources are as follows: Fiala et al. (1987) - 106 whole-rock analyses of granulites from the Moldanubian Zone of the Czech Republic, linking data on mineral composition of the samples and whole-rock geochemistry; Kotková (1993) - 68 wholerock analyses from the Ohře Crystalline Complex, and Janoušek et al. (2004 and references therein) - c. 340 whole-rock data from the Moldanubian Zone including Lower Austria. Fiala et al. (1987) distinguished acid 
pyroxene-free granulites and granulitic gneisses $\left(\mathrm{SiO}_{2}>\right.$ $69 \%, \mathrm{~K}_{2} \mathrm{O}>2.5 \%$ ), subacid to intermediate pyroxene granulites and subacid pyroxene-free granulites $\left(\mathrm{SiO}_{2}<\right.$ $69 \%, \mathrm{~K}_{2} \mathrm{O}<2.5 \%$ ). Janoušek et al. (2004) focused on felsic granulites with $\mathrm{SiO}_{2}>70$ wt. \%. Although the main geochemical characteristics given in the three publications are similar, the petrogenetic interpretations of the more elaborate approach of Janoušek et al. (2004), which includes isotopic data, are in some respects different.

The studies demonstrated that:

- all the granulites show a range of composition from felsic (granitic) to granodioritic-quartz dioritic to mafic (gabbroic) (Fig. 8),

- all the rocks define a calc-alkaline trend in the AFM diagram,

- granulites correspond to medium (intermediate and mafic types) to high-K (acid types) calc-alkaline rocks based on their normative An contents ( > $10 \%$ of eq. $A n)$ and $\mathrm{SiO}_{2}$ vs. $\mathrm{K}_{2} \mathrm{O}$ plot; felsic granulites are weakly to moderately peraluminous $(\mathrm{A} / \mathrm{CNK}=1.05-1.20)$ (Kotková and Harley 1999; Janoušek et al. 2004),
- the $\mathrm{K} / \mathrm{Rb}$ and $\mathrm{Rb} / \mathrm{Sr}$ ratios of all the granulites correspond to LILE-undepleted upper continental crust, which is characteristic of the geotectonic Group I (high-pressure) of the European Variscan granulites as defined by Pin and Vielzeuf (1983),

- all granulite types, and especially those of acid composition, are depleted in Cs, Th and U compared to normal igneous rocks,

- zirconium contents of felsic granulites are lower (Fiala et al. 1987) or similar (Janoušek et al. 2004) in respect to upper crustal rocks such as granites,

- acid granulites are relatively enriched in $\mathrm{Cr}$ and $\mathrm{Ni}$ compared to their upper crustal equivalents (granites, rhyolites), which can be attributed to their intimate association with ultrabasic upper mantle rocks (maybe related to sample contamination during processing - Janoušek pers.com.),

- felsic granulites feature fractionated REE distribution patterns with weak to moderate LREE enrichment and pronounced negative Eu anomalies; these patterns resemble those typical of upper crustal rocks such as

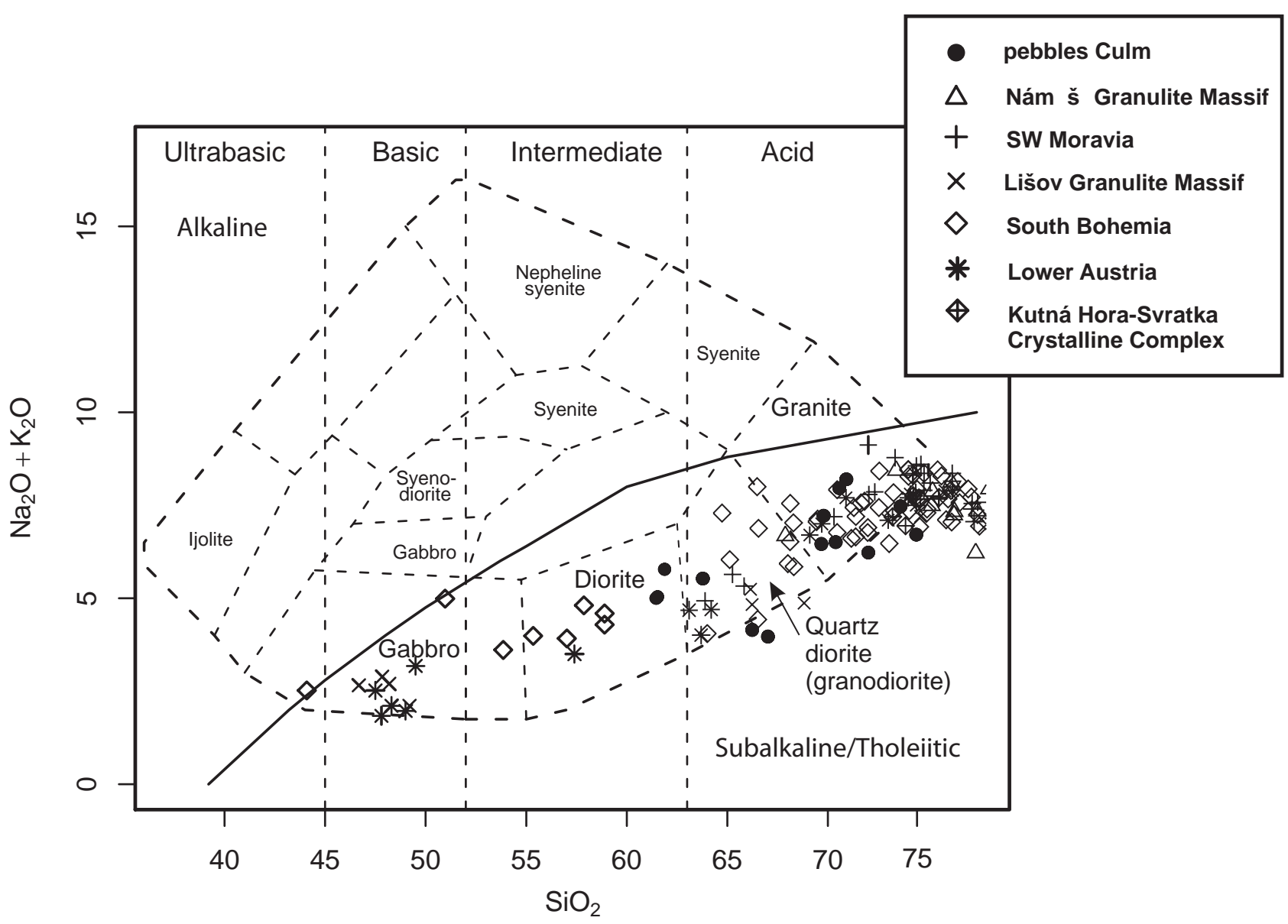

Fig. 8 TAS diagram (Cox et al. 1979) for selected granulite bodies in the Bohemian Massif. Plotted using GCDkit software (Janoušek et al. 2006a). 
granites; total REE (but not HREE) decrease with increasing acidity,

- the acid granulites cluster in the region corresponding to the granite minimum in the normative $\mathrm{Ab}-\mathrm{Qtz}-\mathrm{Or}$ diagram.

Fiala et al. (1987) and Vellmer (1992) concluded that acid granulites probably represent original meta-igneous rocks of granite/rhyolite composition, comparing their geochemistry to rhyolites of bimodal associations and granites, respectively. Pyroxene-bearing granulites were interpreted as metamorphosed acid, subacid and intermediate members of a normal calc-alkaline igneous rock series and subacid pyroxene-free granulites as metamorphosed sediments of arenitic composition. The depletion in Th and $\mathrm{U}$ (and $\mathrm{Zr}$ and $\mathrm{MnO}$ ) has been explained by dehydration during the granulite-facies metamorphism (although, then $\mathrm{K}$ and $\mathrm{Rb}$ should also be depleted) (Fiala et al. 1987).

Kotková and Harley (1999) have proposed that the south Bohemian garnet-kyanite-bearing leucogranulites represent metamorphosed equivalents of HP leucogranites formed by high-pressure water-undersaturated melting near to, or at the time of, the main HP metamorphism. These melts were thought to be fractionated to a variable degree. This interpretation is based on the following evidence:

- high-K peraluminous compositions and low mafic content, similar to leucogranites,

- compositions of the leucogranulites plotting near the minimum melts in the normative Ab-Qtz-Or diagram, the shift away from $A b$ apex being caused by the presence of some An in the system and low water activity, based on experimental works,

- the estimated minimum peak conditions for Moldanubian leucogranulites of $\sim 15 \pm 1$ kbar and $930 \pm 10^{\circ} \mathrm{C}$ (Carswell and O’Brien 1993; Kotková and Harley 1999) located above the dry solidus of muscovite granite and high enough for fluid-deficient melting;

- garnet shows a distinct negative Eu anomaly, which is typical of garnets formed in granulite-facies migmatites and leucogranites and reflects production of K-feldspar as a peritectic phase along with Grt (and kyanite) in the melting reaction - which is constrained to high $\mathrm{P}$ and $\mathrm{T}$ by existing experiments,

- observed HREE partitioning between garnet and whole rock differs from that of garnet-melt HREE partitioning; the relatively low $\mathrm{K}_{\mathrm{d}}$ for HREE in garnet from leucogranulite are thought to reflect removal of a slight percentage of the melt after Grt and Kfs crystallization,

- preserved HREE zoning in Ca-rich high-pressure garnet with rimward HREE decrease and P depletion in the rims reflects growth of garnet in equilibrium with a leucogranitic melt, first as a peritectic phase along with K-feldspar and then in competition with zircon and apatite for HREE and P, respectively.
Jakeš (1997) used the following arguments for his view of felsic granulites as high-pressure dehydration melts:

- pristine mineralogy with Grt and Ky as liquidus phases as well as the estimated high $\mathrm{P}-\mathrm{T}$ conditions for their formation,

- Zr shows a positive correlation with Th and $\mathrm{U}$ and a negative one with LILE (such as Rb), which suggests melting or removal of zircon,

- incorporation of ultramafic, mantle rocks into granulites in the solid state, which have been captured by the granulite melts rising up after the deep subduction.

Janoušek et al. (2004) interpreted the felsic Moldanubian granulites as metamorphosed (partly anatectic) Early Palaeozoic granitic rocks. Their arguments were as follows:

- trace-element contents and variation trends, such as decreasing $\mathrm{Sr}, \mathrm{Ba}, \mathrm{Eu}, \mathrm{LREE}$ and $\mathrm{Zr}$ with increasing $\mathrm{SiO}_{2}$ and $\mathrm{Rb}$, can be explained by fractional crystallization of a granitic magma,

- as shown by mass-balance calculations, high degrees of partial melting ( $>80 \%$ ) would be needed to yield a comparably broad compositional range of partial melts,

- the U, Th and Cs depletion compared to the average upper crust and normal granites has been probably caused by fluid or a slight melt loss (by $0.4-12.5 \%$ as modelled) during the high-grade metamorphism,

- low $\mathrm{Zr}$ and LREE contents yield relatively low zircon and monazite saturation temperatures of $740 \pm 50^{\circ} \mathrm{C}$,

- presence of inherited cores in zircon overgrown by Variscan shells along with low zircon and monazite saturation temperatures are taken as evidence for the low extent of the Variscan HP-HT melting,

- variation in the ${ }^{87} \mathrm{Sr}^{86}{ }^{86} \mathrm{Sr}_{340}$ ratios and preserved Ordovician (Blanský les Massif) or Silurian (Lower Austria) isochron ages shows that the whole-rock Rb-Sr system failed to re-equilibrate during the Variscan high-grade metamorphism,

- the whole-rock geochemical character reflects partial melting of quartzo-feldspathic source, such as orthogneiss; low $\mathrm{Rb} / \mathrm{Sr}$ and $\mathrm{Sr} / \mathrm{Ba}$ ratios discount any significant role of muscovite dehydration melting,

- metagranites and metarhyolites of the Saxothuringian Unit, similar to those from Fichtelgebirge in Germany, were considered as potential protoliths of felsic granulites as they have similar whole-rock geochemical characteristics and Ordovician ages,

- isopleths of melt fractions produced by dehydration melting were calculated in a P-T pseudosection; the initial melting, limited by mica availability, could not exceed 10 vol. \% for any of the granulite decompression paths taken into account - i.e. within the range of 5-15 vol \% previously modelled by Roberts and Finger (1997). 
This and other recent isotope studies have shown that the initial composition of strontium in felsic granulites is highly radiogenic (e.g., Saxony: ${ }^{87} \mathrm{Sr} /{ }^{86} \mathrm{Sr}_{\mathrm{i}}=0.7191$, Romer and Rötzler 2001, Moldanubian Unit: ${ }^{87} \mathrm{Sr}^{86}{ }^{86} \mathrm{Sr}_{340}=$ 0.711-0.770, Janoušek et al. 2004) which indicates their long crustal residence before the granulite-facies event.

\subsection{Protolith zircon dating}

Prismatic zircons from felsic granulites of the BM referred to as "magmatic" or "protolith" zircons can show oscillatory zoning in their cores or throughout, implying crystallization in the equilibrium with melt. Ages of the "magmatic" zircons in leucogranulites from the south Bohemian Moldanubicum are commonly discordant and range between $\sim 360$ and 420 Ma; cores of metamorphic zircons were dated at $\sim 360-470$ Ma (Wendt et al. 1994, TIMS; Kröner et al. 2000, SHRIMP). The first authors interpreted their age of $\sim 370 \mathrm{Ma}$ as the protolith age. This age is similar to that reported by Kröner et al. (2000) for the granodioritic orthogneiss associated with the Prachatice granulite. Oscillatory zoned zircons in quartz dioritic and tonalitic pyroxene granulites of the Lišov granulite massif yielded concordant $\mathrm{U}-\mathrm{Pb}$ ages of 360-370 Ma (combined CL and BSE study of zircon internal zoning and LA-ICP-MS dating). These data have been considered as the protolith crystallization age (Janoušek et al. 2006b). Inherited zircon cores with oscillatory zoning from Lower Austrian leucogranulites yielded strongly scattered, but concordant ages that fall in the time ranges of 450-400 Ma and 480-500 Ma, with the age of $\sim 450 \mathrm{Ma}$ interpreted as granite protolith formation (SHRIMP, Friedl et al. 2003, 2004). Some "magmatic" granulite zircons contain small Early Proterozoic or Cadomian cores (Kröner et al. 2000; Friedl et al. 2004; Janoušek et al. 2006b). Based on these data it appears that the granulites of the Moldanubian Zone in the Bohemian Massif can have various protoliths of Ordovician to Devonian age which also may contain a recycled Proterozoic component.

In support of the early magmatic HP history of some of the leucogranulites, though, U-rich prismatic zircons with oscillatory zoning and showing no inheritance have been dated as about $3 \mathrm{Ma}$ older (but within error) than 338 Ma old U-poor spherical "metamorphic" zircons in a leucogranulite clast sampled from Viséan conglomerates (Kotková et al. in press). This has been interpreted as melting preceding HP metamorphism by a very short period of time.

\subsection{Melting experiments}

A recent experimental study relating directly to the petrogenesis of the BM leucogranulites has been carried out by Tropper et al. (2005). They performed fluid-absent piston cylinder experiments using granite gneiss from the Monotonous Unit of the Moldanubian Zone with the assemblage $\mathrm{Kfs}-\mathrm{Pl}-\mathrm{Qtz}-\mathrm{Bt}-\mathrm{Ms}$ as a starting material. Tropper et al. (2005) considered that its whole-rock composition was similar to some of the felsic granulites of the BM. The experimental conditions were up to $1000{ }^{\circ} \mathrm{C}$ and $16 \mathrm{kbar}$, i.e. peak P-T conditions estimated for the Moldanubian granulites. The experiments yielded $30-40 \%$ of partial melt at the peak conditions, having the mineral assemblage corresponding to the felsic granulite (garnet-ternary feldspar-quartz-kyanite-rutile). Large melt volumes persisted on the retrograde path at $950{ }^{\circ} \mathrm{C} / 14 \mathrm{kbar}$ and $900^{\circ} \mathrm{C} / 12 \mathrm{kbar}$. The authors attribute the melt formation to the reaction $\mathrm{Bt}+\mathrm{Pl}+\mathrm{Qtz}=\mathrm{Grt}+$ ternary feldspar $+\mathrm{L}$. In their model, kyanite in the rocks, as well as large rutile grains, formed during decompression. Tropper et al. (2005) claimed that the latter indirectly confirms the model of Roberts and Finger (1997) of larger melt formation and zircon crystallization along the decompressional path. At the same time, they pointed out that the amount of melt produced at HP was higher than that modelled by Roberts and Finger (1997). It has to be borne in mind, though, that petrological features of the granulites, such as kyanite enclosed in the HP-HT phases (garnet and mesoperthite) or zircon ( $338 \mathrm{Ma}$, Aftalion et al. 1989) and rutile enclosed in high-pressure garnet cannot be denied. These can be hardly explained by decompressional crystallization.

Štípská and Powell (2005) have argued from textural features and calculated phase equilibria that the exsolved ternary feldspars typical of the Moldanubian granulites are inherited vestiges of the protoliths' lower-P, pre-Variscan, igneous crystallization. They moreover questioned the UHT crystallization conditions of the Moldanubian granulites. Their pseudosection approach used a wholerock composition taken from the literature and failed to incorporate all known petrographic details, as well as robust UHT estimates from more basic Grt-Cpx-bearing granulite types (e.g. Carswell and O'Brien 1993; Cooke 2000; O’Brien in press).

In summary, it is generally agreed that granulite formation in the Bohemian Massif involved some degree of melting. However, the extent of melting and its timing in relation to the granulite $\mathrm{P}-\mathrm{T}$ path are still under debate. While some authors (e.g. Vrána and Jakeš 1982; Vrána 1989; Jakeš 1997; Kotková and Harley 1999) suggested that the granulites represent HP rocks crystallized from high-pressure leucogranitic (or syenitic) magmas formed during the Variscan subduction, others envisage only restricted partial melting at peak P-T conditions of subducted and metamorphosed older granites, with possibly more significant melting at MP along the decompressional path 
(Roberts and Finger 1997; Janoušek et al. 2004; Tropper et al. 2005). Scientific discussion can certainly lead to further elucidation of processes of the granulite formation, which can involve both sub-solidus and melting reactions.

\section{Tectonic and geodynamic interpretations}

The formation and preservation of HP granulite assemblages is controlled by their formation at depth by crustal thickening and/or deep subduction followed by exhumation along a steep decompressional $\mathrm{P}-\mathrm{T}$ path, indicating tectonic exhumation without major thermal re-equilibration. In addition, low-strain and fluid-deficient conditions are important prerequisites for the preservation of the HP assemblages. This contrasts with the so-called regional granulite terranes, characterized by medium pressures and exhumed along $\mathrm{P}-\mathrm{T}$ paths dominated by isobaric cooling (Harley 1989).

The upper crustal character of the BM granulites, indicated by whole-rock chemistry, extreme estimated temperatures, high pressures corresponding to mantle depths, involvement of the mantle material and geochronological correspondence of crystallization/quenching of ultramafic mantle rocks with the best age estimate of the HP metamorphic peak in granulites, represent the evidence for the deep tectonic burial along rather high $d P / d T$ gradients (e.g. Vrána 1989; Carswell and O’Brien 1993; Kotková 1993; Vrána 1997; O’Brien and Rötzler 2003; Medaris et al. 2005, 2006).

Petrographic as well as geochronologic data confirm very rapid exhumation of granulites. Obduction and thrusting (Vrána 1989), continued or multiple thrusting/crustal stacking (Willner et al. 1997; Krawczyk et al. 2000), tectonic intrusion aided by partial melts forming at hot granulite-fertile metasediment interfaces (Vrána 1997; Vrána and Šrámek 1999) and buoyancy-driven exhumation subsequent to major thickening terminated by slab break-off (model of Matte 1998; O’Brien 2000; O’Brien and Rötzler 2003) or by lithospheric delamination (Massonne 2006) are the common exhumation scenarios for the HP granulites. The presently favoured model for the exhumation of the Saxonian granulite Massif is the one involving a "hydraulic expulsion" from the orogenic root in the SE and subsequent diapiric rise with associated differential thinning of the overlying lithosphere (cf. model of Chemenda et al. 1995) and extensional unroofing (see DEKORP and Orogenic Processes Working Groups 1999 and references therein).

Numerical modelling of the exhumation-related P-Tt-(d) paths of the HP complexes represents a powerful tool to constrain the exhumation mechanisms. This kind of modelling was applied to the Variscan Erzgebirge dome, composed of juxtaposed tectonometamorphic units including the granulite-bearing Gneiss-Eclogite Unit (Willner et al. 1997, 2000). A model involving (i) crustal thickening due to the continent-continent collision after subduction, (ii) delamination and detachment of the mantle lithosphere under the crustal root, (iii) extensional crustal thinning with external escape of the rocks and (iv) upward channel flow exhuming the lower crustal rocks along with ongoing subduction has been proposed for its formation (Willner et al. 2002). The model of Zulauf et al. (2002 and references therein) is similar in that it suggests exhumation of the lower crust with Ohře Crystalline Complex granulites by a normal movement along a steeply inclined shear zone, developed after important crustal thickening.

An alternative model applied to various parts of the Bohemian Massif is granulite exhumation by vertical extrusion of the orogenic lower crust into the midcrustal levels (Štípská et al. 2004; Schulmann et al. 2005; Tajčmanová et al. 2006a). This model proposes granulite formation in the lower part of the thickened orogenic root system during prolonged convergence of lithospheric plates following subduction. Homogeneous crustal thickening envisaged by these authors is facilitated by the still hot and weak character of the lithosphere after the earlier back-arc extension and associated magmatism (see Schulmann et al. 2005 and references therein). The exhumation of the lower crust to mid-crustal levels and the high exhumation rates at the eastern margin of the $\mathrm{BM}$ are attributed to a continuous indentation (wedging) by the neighbouring Cadomian continent and orogenic channel flow. Subsequent transpressional and transtensional shearing were responsible for the exhumation of the middle crust (Schulmann et al. 2005). Štípská et al. (2004) and Tajčmanová et al. (2006a) both attribute the late stage of granulite exhumation to lateral spreading of the associated high-grade rocks over a mid-crustal (indenting) unit, although at different depths in the respective study areas (35-30 km Rychleby Mts, Orlica-Snieznik Dome, vs. $\sim 12 \mathrm{~km}$ Strážek Unit, Moravian Moldanubicum). Exhumation by near-to-vertical extrusion of the softened orogenic root has been suggested also for the Blanský les Massif (Svojtka et al. 2002). A geometric and kinematic model of viscous flow exhuming the felsic granulites from lower to mid-crustal levels has been proposed for the Blanský les granulites by Franěk et al. (2006). This model is based on a structural and microstructural study. Racek et al. (2006) distinguished two superposed complexes involving the lower crustal (granulite-facies) rocks in the Drosendorf Window. They concluded that the whole assembly was thrust over the mid-crustal unit and disputed the so far widely accepted model of the allochthonous granulite klippen remaining after the long-distance transport of the Gföhl Nappe. 


\section{Conclusions}

The summary presented above, covering a large number of published works, shows that there has been a considerable progress in knowledge on the HP granulites of the Bohemian Massif and processes of their formation and exhumation. It is also evident that there are still many open questions. Their resolution requires multidisciplinary approach and a scientific discussion aiming at understanding the granulite-forming processes, their timing and tectonic interpretations.

Acknowledgements This review is based on my long-time study of the granulites of the Bohemian Massif, started by my $\mathrm{PhD}$ thesis proposed by P. Jakeš and supervised by S. Vrána and J. Klomínský. Further I acknowledge financing by the projects GAČR 205/94/1459, GAČR 205/99/0567, GAČR 205/03/0040 as well as MSM 0021622 2412. On my way towards understanding the granulite-forming processes and techniques of their studies I found as very useful discussions with S. Vrána and P. J. O'Brien. Europrobe Travel Grant and help of R. R. Parrish from NIGL in Keyworth and Axel Gerdes (now Frankfurt University) enabled me to get acquainted with the U-Pb TIMS dating technique and interpretation of geochronological data and to experience the tedious way towards these data acquisition. S. Harley from Edinburgh University assisted me in discovering the world of melting relationships. I am also grateful to V. Janoušek for his introduction to the GCDkit software and for technical support during writing. The paper was written during my stay at Ruhr-Universität Bochum as a Humboldt Fellow. The text profited from a language check and comments by S. Chakraborty, reviewer R. A. Cooke, two other anonymous reviewers as well as editorial work of V. Janoušek.

\section{References}

Aftalion M, Bowes DR, VRÁna S (1989) Early Carboniferous U-Pb zircon age of garnetiferous, hyperpotassic granulites, Blanský les massif, Czechoslovakia. Neu Jb Mineral, Mh 4: 145-52

ARnold A, SCHARBert HG (1973) Rb-Sr-Alterbestimmungen an Granuliten der südlichen Böhmischen Masse in Österreich. Schweiz Mineral Petrogr Mitt 53: 61-78

BECKER H (1996) Geochemistry of garnet peridotite massifs from Lower Austria and the composition of deep lithosphere beneath a Palaeozoic convergent plate margin. Chem Geol 134: 49-65

BECKER H (1997) Sm-Nd garnet ages and cooling history of high-temperature garnet peridotite massifs and highpressure granulites from Lower Austria. Contrib Mineral Petrol 127: 224-236
BEHR HJ (1961) Beiträge zur petrographischen und tektonischen Analyse des sächsischen Granulitgebirges (mit Anlagenmasse). Freib Forschungsh C 119: 1-146

BeHR HJ (1978) Subfluenz-Prozesse im GrundgebirgesStockwerk Mitteleuropas. Z Dtsch Geol Gesell 129: 283-318

Behr H, den Tex E, De Waard D, Mehnert K-H, ScharBERT HG, SOBOLEV VS (1971) Granulites - results of a discussion I. Neu Jb Mineral, Mh: 97-123

Blümel P, Bues C (1995) Exkursion 6: Westrand der Böhmischen Masse: Ostbayrisches Moldanubikum - Gabbroamphibolitmasse von Neukirchen b Hl Blut, SW-Ecke des Bohemikums. Exkursionsführer und Veröffentlichungen 195, Gesellschaft für Geowissenschaften e.V., pp 198-210

Bohlen SR (1987) Pressure-temperature-time paths and a tectonic model for the evolution of granulites. J Geol 95: 617-632

CARswell DA (1991) Variscan high P-T metamorphism and uplift history in the Moldanubian Zone of the Bohemian Massif in Lower Austria. Eur J Mineral 3: 323-342

Carswell DA, O‘Brien PJ (1993) Thermobarometry and geotectonic significance of high-pressure granulites: examples from the Moldanubian zone of the Bohemian Massif in Lower Austria. J Petrol 34: 427-459

Chemenda iA, Mattauer M, Malavielle J, Bokun AN (1995) A mechanism for syn-collisional exhumation and associated normal faulting: results from physical modelling. Earth Planet Sci Lett 132: 225-232

COOKe RA (2000) High-pressure/temperature metamorphism in the St. Leonhard Granulite Massif, Austria: evidence from intermediate pyroxene-bearing granulites. Int J Earth Sci 89: 631-651

CoOKe RA, O‘Brien PJ (2001) Resolving the relationship between high $\mathrm{P}-\mathrm{T}$ rocks and gneisses in collisional terranes: an example from the Gföhl gneiss-granulite association in the Moldanubian Zone, Austria. Lithos 58: 33-54

Cooke RA, O`Brien PJ, CARswell DA (2000) Garnet zoning and the identification of equilibrium mineral compositions in high-pressure-temperature granulites from the Moldanubian Zone, Austria. J Metamorph Geol 18: 551-569

Cox KG, Bell J D, Pankhurst RJ (1979) The Interpretation of Igneous Rocks. George Allen \& Unwin, London, pp 1-450

Čopjaková R, Sulovský P, Paterson BA (2005) Major and trace elements in pyrope-almandine garnets as sediment provenance indicators of the Lower Carboniferous Culm sediments, Drahany Uplands, Bohemian Massif. Lithos 82: $51-70$

DEKORP and Orogenic Processes Working Groups (1999) Structure of the Saxonian Granulites: geological and geophysical constraints on the exhumation of high- 
pressure/high-temperature rocks in the mid-European Variscan belt. Tectonics 18: 756-773

Dodson MH (1973) Closure temperature in cooling geochronological and petrological systems. Contrib Mineral Petrol 40: 259-274

FediuKovÁ E (1965) Ultrabasic xenoliths in the granulite at Mt. Klet' near Český Krumlov. Acta Univ Carol, Geol 3: 189-202

Fediuková E (1971) Andalusite in granulites of the Bohemian Massif. Tschermaks Mineral Petrogr Mitt 15: 249-267

Fiala J, MatěJovská O, VañKová V (1987) Moldanubian granulites and related rocks: petrology, geochemistry, and radioactivity. Rozpr Česk Akad Věd Mat Nat Sci Ser 97: 1-102

Finger F, Clemens J (1995) Migmatization and 'secondary' granitic magmas: effects of emplacement and crystallization of 'primary' granitoids in South Bohemia, Austria. Contrib Mineral Petrol 120: 311-326

FIšERA M, KotKovÁ J (eds) (1992) International workshop „High Pressure Granulites - Lower Crustal Metamorphism“. June 27-July 5, 1992, Rohanov, Czechoslovakia. Abstract volume. Czech Geological Survey, Prague, pp $1-28$

FraněK J, Schulmann K, Lexa O (2006) Kinematic and rheological model of exhumation of high pressure granulites in the Variscan orogenic root: example of the Blanský les granulite, Bohemian Massif, Czech Republic. Mineral Petrol 86: 253-276

Franke W (1984) Variszischer Deckenbau im Raume der Münchberger Gneismasse - abgeleitet aus der Fazies, Deformation und Metamorphose im umgebended Paläozoikum. Geotekt Forsch 68: 1-253

Franke W (2000) The mid-European segment of the Variscides: tectonostratigraphic units, terrane boundaries and kinematic evolution. In: Franke W, Haak V, Oncken O, Tanner D (eds) Orogenic processes: Quantification and Modelling in the Variscan Belt. Geol Soc Lond Spec Publ 179: 35-63

Friedl G, Cooke R, Finger F, McNaughton NJ, Fletcher A (2003) U-Pb SHRIMP dating and trace element investigations on multiple zoned zircons from a South-Bohemian granulite. J Czech Geol Soc 48: 51-52

Friedl G, Finger F, Paquette JL, von Quadt A, McNaughton NJ, Fletcher IR (2004) Pre-Variscan geological events in the Austrian part of the Bohemian Massif deduced from U/Pb zircon ages. Int J Earth Sci 93: 802-823

Fuchs G, Matura A (1976) Zur Geologie des Kristallins der südlischen Böhmischen Masse. Jb Geol B-A 119: 1-43

Gayk T, Kleinschrodt R, Langosch A, Seidel E (1995) Quartz exsolution in clinopyroxenes of high-pressure granulites from the Münchberg massif. Eur J Mineral 7: $1217-1220$
Gordon SM, Schneider DA, Manecki M, Holm DK (2005) Exhumation and metamorphism of an ultrahigh-grade terrane: geochronometric investigations of the Sudete Mountains (Bohemia), Poland and Czech Republic. J Geol Soc London 162: 841-855

GREEN DH, LAMBERT IB (1965) Experimental crystallization of anhydrous granite at high pressures and temperatures. J Geophys Res 70: 5259-5268

Green DH, Ringwood AE (1967) An experimental investigation of gabbro to eclogite transformation and its petrological applications. Geochim Cosmochim Acta 31: 767-833

Grew ES (1986) Petrogenesis of kornerupine at Waldheim (Sachsen), German Democratic Republic. Z Geol Wiss 14: 525-558

GREW ES (1989) A second occurrence of kornerupine in Waldheim, Saxony, German Democratic Republic. Z Geol Wiss 17: 67-76

GÜRTLEROVÁ P ET AL. (1997) Database of analytical determinations on maps of rock geochemical reactivity 1: 50000 . In: Lithogeochemical Database of the Czech Geological Survey, Prague

HARLEY SL (1989) The origins of granulites: a metamorphic perspective. Geol Mag 126: 215-247

HolLAND TJB (1980) The reaction albite = jadeite + quartz determined experimentally in the range $600-1200^{\circ} \mathrm{C}$. Am Mineral 65: 129-134

JAKEŠ P (1969) Distribution of the granulites within the Bohemian Massif and their petrological features. Spec Publ Geol Soc Aust 2: 269-277

JAKEŠ P (1997) Melting in high-P region - case of Bohemian granulites. Acta Univ Carol, Geol 41: 113-125

JANOUŠEK V (ed) (2004) International Workshop on Petrogenesis of Granulites and Related Rocks, Náměšt' nad Oslavou, October 1-3, 2004. Excursion Guide \& Abstract Volume. Moravian Museum, Brno, pp 1-72

JANoušeK V, Holub F V (2007) The causal link between HP-HT metamorphism and ultrapotassic magmatism in collisional orogens: case study from the Moldanubian Zone of the Bohemian Massif. Proc Geol Assoc 118: 75-86

Janoušek V, Finger F, Roberts MP, Frýda J, Pin C, Dolejš D (2004) Deciphering petrogenesis of deeply buried granites: whole-rock geochemical constraints on the origin of largely undepleted felsic granulites from the Moldanubian Zone of the Bohemian Massif. Trans Roy Soc Edinb, Earth Sci 95: 141-159

JANOUŠEK V, FARRow C M, ERBAN V (2006a) Interpretation of whole-rock geochemical data in igneous geochemistry: introducing Geochemical Data Toolkit (GCDkit). J Petrol 47: 1255-1259

Janoušek V, Gerdes A, Vrána S, Finger F, Erban V, Friedl G, BRAithwaIte CJR (2006b) Low-pressure granulites of the Lišov Massif, southern Bohemia: Viséan meta- 
morphism of Late Devonian plutonic arc rocks. J Petrol 47: 705-744

KLEMD R, BRÖCKER M (1999) Fluid influence on mineral reactions in ultrahigh-pressure granulites: a case study in the Snieznik Mts. (West Sudetes, Poland). Contrib Mineral Petrol 136: 358-373

Klötzli UF, Koller F, Scharbert S, Höck V (2000) Cadomian lower-crustal contributions to Variscan granite petrogenesis (South Bohemian Pluton, Austria): constraints from zircon typology and geochronology, wholerock, and feldspar Pb-Sr isotope systematics. J Petrol 43: 1783-1786

Kodym O (1972) Multiphase deformation of the Blanský les Granulite Massif (southern Bohemia). Krystalinikum 9: 91-105

Kodym O, JaKeš P, SchovÁNeK P (1978) Granulite und ultramafische Gesteine aus der Strukturbohrung Holubov. Sbor geol Věd, Geol 32: 7-47

KonopáseK J, Schulmann K (2005) Contrasting Early Carboniferous field geotherms: evidence for accretion of a thickened orogenic root and subducted Saxothuringian crust (Central European Variscides). J Geol Soc, London 162: 463-470

Kotкоvá J (1993) Tectonometamorphic history of lower crust in the Bohemian Massif - example of north Bohemian granulites. Spec Pap Czech Geol Survey 2: pp 1-42

KoтKоVÁ J (1995) Contrasting exhumation mechanism of Bohemian Massif granulite bodies. Terra Abstracts 7: 122

KоткоVÁ J (1998a) Garnet-bearing mafic granulites from the Lišov Granulite Massif. Geolines 6: 37

KоткоVÁ J (1998b) Garnet-pyroxene-bearing granulites from the Lišov Granulite Massif. MS, Czech Geological Survey, Prague, pp 1-24 (in Czech)

KotKová J, Harley SL (1999) Formation and evolution of HP leucogranulites: experimental constraints and unresolved issues. Phys Chem Earth (A) 24: 299-304

Kotková J, Kröner A, Todt W, Fiala J (1996) Lower Carboniferous high-pressure event in the Bohemian Massif: evidence from North Bohemian granulites. Geol Rundsch 85: $154-161$

KotKová J, Harley SL, FišERA M (1997) A vestige of very high-pressure (ca. 28 kbar) metamorphism in the Variscan Bohemian Massif, Czech Republic. Eur J Mineral 9: 1017-1033

Kotková J, Gerdes A, Parrish R, Novák M (2007) U-Pb chronology of clasts of exotic high-grade rocks within Upper Viséan conglomerates, Variscan belt, Central Europe. J Metamorphic Geol (in press)

Krawczyk CM, Stein E, Choi S, Oettinger G, Schuster K, Götze H-J, Haak V, Oncken O, Prodehl C, Schulze A (2000) Geophysical constraints on exhumation mechanisms of high-pressure rocks: the Saxo-Thuringian case between the Franconian Line and Elbe Zone. In: Franke W, Haak V, Oncken O, Tanner D (eds) Orogenic Processes: Quantification and Modelling in the Variscan Belt. Geol Soc London Spec Publ 179: 303-322

KRÖNER A, WiLLNER A (1998) Time of formation and peak of Variscan HP-HT metamorphism of quartz-feldspar rocks in the central Erzgebirge, Saxony, Germany. Contrib Mineral Petrol 132: 1-20

Kröner A, Wendt I, Liew TC, Compston W, Todt W, Fiala J, VAŇKovÁ V, VANĚK J (1988) U-Pb zircon and Sm-Nd model ages of high-grade Moldanubian metasediments, Bohemian Massif, Czechoslovakia. Contrib Mineral Petrol 99: 257-266

Kröner A, O’Brien PJ, Nemchin AA, Pidgeon RT (2000) Zircon ages for high pressure granulites from South Bohemia, Czech Republic, and their connection to Carboniferous high temperature processes. Contrib Mineral Petrol 138: 127-142

Kryza R, Pin C, Vielzeuf D (1996) High-pressure granulites from the Sudetes (south-west Poland): Evidence of crustal subduction and collisional thickening in the Variscan Belt. J Metamorph Geol 14: 531-546

Lange U, Bröcker M, Armstrong R, Trapp E, Mezger $\mathrm{K}$ (2005) Sm-Nd and U-Pb dating of high-pressure granulites from the Zlote and Rychleby Mts (Bohemian Massif, Poland and Czech Republic). J Metamorph Geol 23: 133-145

Massonne HJ (2001) First find of coesite in the ultrahighpressure metamorphic region of the Central Erzgebirge, Germany. Eur J Mineral 13: 565-570

Massonne HJ (2006) Early metamorphic evolution and exhumation of felsic high-pressure granulite from the northwestern Bohemian Massif. Mineral Petrol 86: 177-202

Matte P, Maluski H, Rajlich P, Franke W (1990) Terrane boundaries in the Bohemian Massif: result of large-scale Variscan shearing. Tectonophysics 177: 151-170

Matтe P (1998) Continental subduction and exhumation of HP rocks in Palaeozoic orogenic belts: Uralides and Variscides. Geologiska Föreningens I Stockhol Förhandlingar 120: 209-222

Medaris LG, Beard BL, Johnson CM, Halley JW, SpicuzZa MJ, JeLínek E, MísaŘ Z (1995) Garnet pyroxenite and eclogite in the Bohemian Massif - geochemical evidence for Variscan recycling of subducted lithosphere. Geol Rundsch 84: 489-505

Medaris LG, Wang H, Jelínek E, Mihaljevič M, Jakeš P (2005) Characteristics and origins of diverse Variscan peridotites in the Gföhl Nappe, Bohemian Massif. Lithos 82: $1-23$

Medaris LG, Beard B, Jelínek E (2006) Mantle-derived UHP pyroxenite and eclogite in the Moldanubian Gföhl Nappe, Bohemian Massif: a geochemical review, new $\mathrm{P}-\mathrm{T}$ determinations, and tectonic interpretation. Int Geol Rev 48: 765-777 
MeHNERT KR (1972) Granulites - Results of a discussion II. Neu Jb Mineral, Mh: 139-150

Mezger K (1990) Geochronology in granulites. In Vielzeuf D, Pin C (eds) Granulites and Crustal Evolution. Kluwer Academic Publishers, Dordrecht, pp. 451-470

Nasdala L, Massonne HJ (2000) Microdiamonds from Saxonian Erzgebirge, Germany: in situ micro-Raman characterisation. Eur J Mineral 12: 495-498

Newton RC, Haselton HT (1981) Thermodynamics of the garnet-plagioclase- $\mathrm{Al}_{2} \mathrm{SiO}_{5}$-quartz geobarometer. In: Newton RC, Navrotsky A, Wood BJ (eds) Thermodynamics of Minerals and Melts. Springer-Verlag, New York, pp 131-147

NovÁK M, PovondRa P (1984) Wagnerite from Skřináŕov, central Czechoslovakia. Neu Jb Mineral, Mh 536-542

O'BriEN PJ (1999) Asymmetric zoning profiles in garnet from HP-HT granulite and implications for volume and grain-boundary diffusion. Mineral Mag 63: 227-238

O’BRIEN PJ (2007) Challenges in high-pressure granulite metamorphism: reaction textures, compositional zoning, ages and tectonic interpretation with examples from the Bohemian Massif. J Metamorph Geol (in press)

O’BRIEN PJ (2006) Type-locality granulites: high-pressure rocks formed at eclogite-facies conditions. Mineral Petrol 86: $161-175$

O’BRIen PJ, RÖTZLER J (2003) High-pressure granulites: formation, recovery of peak conditions and implications for tectonics. J Metamorph Geol 21: 3-20

O’Brien PJ, Kröner A, Jaeckel P, Hegner E, Zelazniewicz A, KryzA R (1997) Petrological and isotopic studies on Palaeozoic high-pressure granulites, Gory Sowie Mts, Polish Sudetes. J Petrol 38: 433-456

Opletal M, Vrána S (1989) Charnockite xenoliths in the Tertiary volcanites of the České středohoří Mts., northern Bohemia. Sbor geol Věd, Geol 44: 51-78

O'Hara MJ, Richardson SW, Wilson G (1971) Garnetperidotite stability and occurrence in crust and mantle. Contrib Mineral Petrol 32: 48-68

Owen JV, Dostal J (1996a) Contrasting corona structures in mafic granulite from the Blanský Les complex, Bohemian Massif, Czech Republic. Canad Mineral 34: 959-966

Owen JV, Dostal J (1996b) Prograde metamorphism and decompression of the Gföhl gneiss, Czech Republic. Lithos 38: 259-270

Petrakakis K (1997) Evolution of Moldanubian rocks in Austria: review and synthesis. J Metamorph Geol 15: 203-222

Pidgeon RT, Bowes DR (1972) U-Pb ages of granulite from the Central Region of the Lewisian, northwestern Scotland. Geol Mag 109: 247-258

Pin C, Vielzeuf D (1983) Granulites and related rocks in Variscan Median Europe: a dualistic interpretation. Tectonophysics 93: 47-74
Pin C, Vielzeuf D (1988) Les granulites de haute-pression d'Europe moyenne temoins d'une subduction eo-hercynienne; implications sur l'origine des groupes leptyno-amphiboliques. Bull Soc Géol Fr 4: 13-20

Prince CI, Košler J, Vance D, Günter D (2000) Comparison of laser ablation ICP-MS and isotope dilution REE analyses - implications for Sm-Nd garnet geochronology. Chem Geol 168: 255-274

Racek M, Štípská P, Pitra P, Schulmann K, LeXa O (2006) Metamorphic record of burial and exhumation of orogenic lower and middle crust: a new tectonothermal model for the Drosendorf window (Bohemian Massif, Austria). Mineral Petrol 86: 221-251

ROBERTS MP, FingER F (1997) Do U-Pb zircon ages from granulites reflect peak metamorphic conditions? Geology 25: 319-322

ROMER RL, RÖTZLER J (2001) P-T-t evolution of ultrahightemperature granulites from the Saxon Granulite Massif, Germany. Part II: Geochronology. J Petrol 42: 2015-2032

RÖTZLER J, ROMER RL (2001) P-T-t evolution of ultrahightemperature granulites from the Saxon Granulite Massif, Germany. Part I: Petrology. J Petrol 42: 1995-2013

Scharbert HG (1964) Die Granulite des südlichen niederösterreichischen Moldanubikums. Neu Jb Mineral, Abh 101: 210-232

Scharbert HG (1971) Cyanit und Sillimanit in moldanubischen Granuliten. Tschermaks Mineral Petrogr Mitt 16: 252-267

Scharbert HG, Kurat G (1974) Distribution of some elements between coexisting ferromagnesian minerals in Moldanubian granulite facies rocks, Lower Austria, Austria. Tschermaks Mineral Petrogr Mitt 42: 110-134

Schenk V, Todt W (1983) U-Pb Datierungen an Zirkon und Monazit der Granulite im Moldanubikum Niederösterreichs (Waldviertel). Fortschr Mineral 61: 190-191

SCHREYER W (1985) Metamorphism of crustal rocks at mantle depths: high-pressure minerals and mineral assemblages in metapelites. Fortschr Mineral 63: 227-261

Schreyer W, Abraham K, Behr HJ (1975) Sapphirine and associated minerals from the kornerupine rock of Waldheim, Saxony. Neu Jb Mineral, Abh 126: 1-27

Schulmann K, Kröner A, Hegner E, Wendt I, Konopásek J, LEXA O, ŠTíPSKÁ P (2005) Chronological constraints on the pre-orogenic history of deep-seated rocks along the eastern margin of the Variscan orogen, Bohemian Massif, Czech Republic. Amer J Sci 305: 407-448

Sláma J, Košler J, Schaltegger U, Tubrett M, Gutjahr M (2006) New natural zircon standard for laser ablation ICP-MS U-Pb geochronology. Winter Conference on Plasma Spectrochemistry, Tucson, Arizona, January 8-14, 2006. ICP Information Newsletter 31: 187-188

SPEAR FS (1993) Metamorphic phase equilibria and pressure-temperature-time paths. Mineralogical Society of America, Michigan, pp 1-779 
STAŇKovÁ J (1982) „Dist-sillimanite“: its importance for assessment of polyphase metamorphism in the leptynite body near Bory, Czechoslovakia. Krystalinikum 16: 53-66

SuEss FE (1926) Intrusionstektonik und Wandertektonik im variszischen Grundgebirge. Bornträger, Berlin

SvojtKa M, KošLer J, Venera Z (2002) Dating granulitefacies structures and the exhumation of lower crust in the Moldanubian Zone of the Bohemian Massif. Int J Earth Sci 91: 373-385

SyneK J, Oliveriová D (1993) Terrane character of the northeast margin of the Moldanubian Zone: the Kutná Hora Crystalline Complex, Bohemian Massif. Geol Rundsch 82: 566-582

ŠTELCL J (1960) Petrography of Culm conglomerates of the southern part of the Drahany Upland. Fol Uni Purkyn Brunen Geol 1: 1-103 (in Czech)

ŠTíPSKÁ P, PowELl R (2005) Does ternary feldspar constrain the metamorphic conditions of high-grade meta-igneous rocks? Evidence from orthopyroxene granulites, Bohemian Massif. J Metamorph Geol 23: 627-647

ŠTíPská P, Schulmann K, KRÖNer A (2004) Vertical extrusion and middle crustal spreading of omphacite granulite: a model of syn-convergent exhumation (Bohemian Massif, Czech Republic). J Metamorph Geol 22: 179-198

Tajčmanová L, Konopásek J, Schulmann K (2006a) Thermal evolution of the orogenic lower crust during exhumation within a thickened Moldanubian root of the Variscan belt of Central Europe. J Metamorph Geol 24: 119-134

Tajčmanová L, Konopásek J, Connolly AD (2006b) Diffusion-controlled development of silica-undersaturated domains in felsic granulites of the Bohemian Massif (Variscan belt of Central Europe). Contrib Mineral Petrol 153: 237-250

Tichomirowa M, Whitehouse MJ, Nasdala L (2005) Resorption, growth, solid state recrystallisation, and annealing of granulite facies zircon - a case study from the Central Erzgebirge, Bohemian Massif. Lithos 82: 25-50

Tollmann A (1982) Grossraumiger variszischer Deckenbau im Moldanubikum und neue Gedanken zum Variszikum Europas. Geotekt Forsch 64: 1-91

Tollmann A (1995) Das Ausmass des variszischer Deckbaues im Moldanubikum. Krystalinikum 18: 117-132

Tropper P, KonzetT Y, Finger F (2005) Experimental constraints on the formation of high-P/high-T granulites in the Southern Bohemian Massif. Eur J Mineral 17: 343-356

van Breemen O, Aftalion M, Bowes DR, Dudek A, Mísař Z, Povondra P, VRÁna S (1982) Geochronological studies of the Bohemian Massif, Czechoslovakia, and their significance in the evolution of Central Europe. Trans Roy Soc Edinb, Earth Sci 73: 89-108

Vellmer C (1992) Stoffbestand und Petrogenese von Granuliten und granitischen Gesteinen der südlichen Böhmisch- en Masse in Niederösterreich. Unpublished PhD. thesis, Georg-August-Universität, Göttingen, pp 1-111

von Justi JHG (1754) Nachricht von einer neuen Art eines neues Halbedelgesteines so kürtzlich in Mähren entdeckt worden. Neue Wahrheiten zumVorteil der Naturkunde und des gesellschaftlichen Leben der Menchen 1

Vielzeuf D, Pin C (1989) Geodynamic implications of granulitic rocks in the Hercynian belt. In: Daly JS, Cliff RA, Yardley BWD (eds) Evolution of Metamorphic Belts. Geol Soc London Spec Publ 43: 343-348

VRÁNA S (1979) Polyphase shear folding and thrusting in the Moldanubicum of southern Bohemia. Věst Ústř Úst Geol 54: 75-86

VRÁNA S (1987) Garnet-fassaitic pyroxene skarn from the granulite complex of southern Bohemia. Bull Czech Geol Surv 62: 193-206

VRÁNA S (1989) Perpotassic granulites from southern Bohemia - a new rock type derived from partial melting of crustal rocks under upper mantle conditions. Contrib Mineral Petrol 103: 510-522

VRÁnA S (1992a) Lom pod Libínem - quarry. In Fiala J, Fišera M, Jelínek E, Slabý J, Vrána S (eds) Excursion Guide, International workshop High-pressure Granulites - Lower Crustal Metamorphism, June 27-July 5, 1992, Rohanov, Czechoslovakia. Czech Geological Survey, Prague, pp 7-8

VRánA S (1992b) The Moldanubian Zone in southern Bohemia: Polyphase evolution of imbricated crustal and upper mantle segments. In: Kukal Z (ed) Proceedings of the $1^{\text {st }}$ International Conference on the Bohemian Massif, Prague, September 26-October 3, 1988, pp 331-335

VRÁNA S (1997) Geology and petrology of the Moldanubian Zone. Tectonics of the Moldanubian Zone. In: Vrána S, Štědrá V (eds) Geological Model of the Western Bohemia Related to the KTB Borehole in Germany. Sbor Geol Věd, Geol 47: pp 109-123

VRÁNA S, FRÝDA J (2003) Ultrahigh-pressure grossular-rich garnetite from the Moldanubian Zone, Czech Republic. Eur J Mineral 15: 43-54

VRÁNA S, JAKEŠ P (1982) Orthopyroxene and two-pyroxene granulites from a segment of charnockitic crust in southern Bohemia. Bull Czech Geol Surv 57: 129-143

VRÁNA S, NovÁK M (2000) Petrology and geochemistry of granulite clasts in the Visean Luleč conglomerate, Kulm in central Moravia, Czech Republic. Bull Czech Geol Surv 75: 405-413

VRÁNA S, ŠRÁmeK J (1999) Geological interpretation of detailed gravity survey of the granulite complex in southern Bohemia and its structure. Bull Czech Geol Surv 74: 261-277

VRÁNA S, ŠtĚDRÁ V, FišERA M (2005) Petrology and geochemistry of the Běstvina granulite body metamorphosed at eclogite facies conditions, Bohemian Massif. J Czech Geol Soc 50: 81-94 
WeIss CS (1803) Über die Gebirgsart des sächsischen Erzgebirges, welche unter dem Namen Weiss-Stein neuerlich bekannt gemacht worden ist. Neue Schriften Gesellschaft Naturforschender Freunde 4: 342-366

Wendt JI, Kröner A, Fiala J, Todt W (1994) U-Pb zircon and Sm-Nd dating of Moldanubian HP/HT granulites from south Bohemia, Czech Republic. J Geol Soc, London 151: 83-90

Willner AP, Rötzler K, Maresch WV (1997) Pressuretemperature and fluid evolution of quartzo-feldspathic metamorphic rocks with a relic high-pressure, granulite-facies history from the Central Erzgebirge (Saxony, Germany). J Petrol 38: 307-336

Willner AP, Krohe A, Maresch WV (2000) Interrelated $\mathrm{P}-\mathrm{T}-\mathrm{t}-\mathrm{d}$ paths in the Variscan Erzgebirge Dome (Saxony, Germany): constraints on the rapid exhumation of highpressure rocks form the root zone of a collisional orogen. Int Geol Rev 42: 64-85

Willner AP, Sebazungu E, Gerya TV, Maresch WV, Krohe A (2002) Numerical modelling of PT-paths related to rapid exhumation of high-pressure rocks from the crustal root in the Variscan Erzgebirge Dome (Saxony/Germany). J Geodyn 33: 281-314

WinkLER HGF (1976) Petrogenesis of Metamorphic Rocks. Springer-Verlag, New York, pp 1-334

Zack T, Moraes R, Kronz A (2004) Temperature dependence of $\mathrm{Zr}$ in rutile: empirical calibration of a rutile thermometer. Contrib Mineral Petrol 148: 471-488

ZoubeK V (1946) Remarks to the question of skarns, granulites and south Bohemian graphite deposits. Contributions to stratigraphy of the crystalline of the Bohemian Massif II. Sb St geol Úst Čsl Repub 13: 483-498 (in Czech)

Zoubek V, Fiala J, Vaňková V, Machart J, Stettner G (1988) Moldanubian Region. In: Zoubek V, Cogné J, Kozhoukharov D, Kräutner HG (eds) Precambrian in Younger Fold Belts, European Variscides, the Carpathians and Balkans. J. Wiley and Sons, Chichester, pp 183-267

Zulauf G, Dörr W, Fiala J, KotKová J, Maluski H, ValVERDE-VAQUERo P (2002) Evidence for high-temperature diffusional creep preserved by rapid cooling of lower crust (North Bohemian shear zone, Czech Republic). Terra Nova 14: 343-354 